\title{
Генри КмиффорА
}

\section{ЖИЗНЕОПИСАНИЕ АЕАИ АЖЕЙН АОРМЕР, ГЕРЦОГИНИ ФЕРИЯ ${ }^{*}$}

\section{Глава I \\ Происхождение леди Джейн Дормер и ее появление на свет}

Родители леди Джейн Дормер принадлежали к древнейшим и благороднейшим семействам Англии, как по крови, так и по доблести и добродетели. Об этом был хорошо осведомлен кардинал Николя де Пеллеве, архиепископ Реймсский и первый пэр Франции ${ }^{1}$, когда он 2 апреля 1593 г. от имени трех сословий этого королевства отвечал на речь ее сына, герцога Ферии ${ }^{2}$, посла короля Филиппа $\mathrm{II}^{3}$ к Лиге в Париже. «Не могу, - сказал архиепископ - не упомянуть, что Ваша мать, ведущая род от лучших семей Англии, ежедневно от щедрот своих оказывает помощь и поддержку несчастным беженцам из-за веры, прибывшим в Испанию: англичанам, ирландцам и шотландцам».

* Перевод подготовлен по изданию: Clifford H. Life of Jane Dormer, Duchess of Feria / ed. by J. Stevenson, S.J. L., 1887.

1 Николя де Пеммеве (1518-1594), архиепископ Реймсский, сторонник Католической ^иги. Возглавлял первое сословие (Ауховенство) на Генеральных Штатах 1593 г.

2 Лоренсо Суарес де Фигероа и Кордоба, 2-й герцог Ферия (1559-1607), испанский посол в Риме (1591-1592), Франции (1593-1595) - именно в этом качестве он присутствовал на заседаниях Генеральных Штатов, обсуждавших избрание короля; позднее - вице-король Каталонии и Сицилии.

3 Филипп II Габсбург (1527-1598), король Испании (1556-1598), Неаполя (1554-1598), Англии (1554-1558), Португалии (1581-1598), герцог Миманский (1540-1598).

Перевод: Анна Юрьевна Серегина, А.и.н., в.н.с. ОтАеления историкотеоретических исслеАований ИВИ РАН, aseregina@mail.ru

DOI: 10.32608/2307-8383-2019-27-271-349 
Семья Дормеров (как я узнал из старой родословной, подтвержденной преданием), сначала жила в Нормандии, когда там скрывался король Эдуард Исповедник ${ }^{4}$, бежавший от тирании Гарольда Заячьей Лапы ${ }^{5}$, сына узурпировавшего королевство короля Кнута ${ }^{6}$. Когда преемник Гарольда Хардакнут ${ }^{7}$ вызвал принца Эдуарда домой из Нормандии, в его свите, среди прочих нормандских дворян, которым пожаловали важные должности, был и Тома д’Ормер. Согласно старинному преданию, во время войн с датчанами и эрлом Годвином ${ }^{8}$ королю Эдуарду помогли деньги, одолженные ему Тома д’Ормером. После победоносного завершения этих войн д’Ормер пригласил короля к себе на обед. Во время обеда он приказал подать на блюде деревянные бирки, обозначавшие количество одолженных королю денег, и, сказав, что у него нет другого способа выказать свою благодарность за оказанную его дому честь, кроме этих бирок, и бросил их в огонь. По числу бирок король понял размер своего долга и величие дара, и ответил, ссылаясь на происхождение имени: «Поистине зовут тебя д’Ормер ${ }^{9}$, ибо нужно иметь море золота, чтобы поступить так, как ты». Говорят, что в память об этом событии был изменен герб Дормеров; ранее на нем был восстающий лев, чернью по золотому полю, а добавлены десять золотых брусков на лазоревом поле, со львом во главе.

Некоторые могут возразить, что ни имени Томаса Дормера, ни такого деяния не найти в исторических трудах, а также, что в это время еще не использовали гербов, чтобы отличать знатные семьи друг от друга. Однако Стоу в своей Английской Хронике ${ }^{10}$ (p. 94) пишет, что король Эдвард привез с собой из Нормандии

4 ЭАуарА Исповедник (ок. 1003-1066), король Англии в 1042-1066 гг., канонизирован в 1161 г. Провел юность в изгнании в Нормандии и вернулся в Англию в 1041 г. как наслеАник короля Хардакнута.

5 ГарольА Заячья Лапа (ок. 1016-1040), король Англии в 1035-1040 гг.

6 Кнут (995-1035) - король Аании (1018-1035), Англии (1016-1035) и Норвегии (1028-1035).

7 Хардакнут (1018-1042) - король Англии в 1040-1042 гг.

8 ГоАвин (ок. 1001-1053) - эрл Уэссекса.

9 От фр. "or" - золото, "mer" - море.

10 Имеются в виду "Анналы, или Великая Хроника Англии" историка и антиквария Ажона Стоу (ок. 1525-1605). 


\section{Генри Клиффорд. Жизнеописание леди Джейн Дормер}

многих дворян и назначил их на высокие должности, но по имени названы только двое прелатов. Почему бы Тома д’Ормеру не быть одним из многих? А в память о службе, какую Тома д’Ормер сослужил своему королю, какой-либо из позднейших государей мог даровать герб в том виде, каков он сейчас. Ведь так поступали многие правители по отношению к потомкам тех, чьи благородные подвиги заслужили благодарность страны.

Сыном этого Тома был Гильом д’Ормер, прибывший вместе с нормандцами, когда король Вильгельм ${ }^{11}$ завоевал Англию. Его сына звали тоже Гильом (Уильям), и его род по прямой мужской линии продолжается до нынешнего 1616 г. Теперешний лорд Дормер ${ }^{12}$

единственный брат герцогини Ферия, и среди его предков был сэр Уильям Дормер, доблестно служивший королю Эдуарду III $^{13}$ в его войнах с Францией около 1350 г. Другой предок, Джеффри Дормер, живший во времена короля Генриха $\mathrm{VI}^{14}$, имел двадцать шесть детей, по большей части сыновей. В мои задачи, однако, не входит подробно рассказывать обо всех предках, но лишь о тех, кто имел отношение к рождению, воспитанию и жизни Джейн Дормер.

Роберт Дормер ${ }^{15}$, впоследствии сэр Роберт, дед нашей герцогини, женился на Джейн ${ }^{16}$, дочери Джона Ньюдигейта из Харфил-

11 Вильгельм І Завоеватель (1027-1087), король Англии в 1066-1087 гг.

12 Роберт, барон Аормер (1551-1616), сын сэра Уильяма Аормера от его второго брака, сводный брат Ажейн Аормер.

13 Эдуард III Плантагенет (1312-1377), король Англии в 1327-1377 гг.

14 Генрих VI ^анкастер (1421-1471), король Англии в 1422-1461 и 14701471 гг.

15 Сэр Роберт Аормер (1485/86-1552), сын Уильяма Аормера из Хай Уикема и его жены Агнес Вудвил, Аочери (незаконнорожденной?) Ричарда Вудвила, графа Риверса. Вопреки словам автора, Аормеры не могли похвастаться знатным происхождением: все они, вкюючая сэра Роберта, занимались разведением овец и торговлей шерстью. Богатство, влияние в графстве и отАаленное родство с королем (Агнес Вудвил была сестрой Элизабет, жены ЭАуарда IV и бабушки Генриха VIII) принесло ему ок. 1535 г. рыцарское звание.

16 Ажейн НьюАигейт (ум. 1568), старшая из детей Ажона Ньюдигейта и Амфиллис Невимл (см. ниже). 
да в Миддлсексе ${ }^{17}$ и дамы Амфиллис Невилл из дома Уэстморлендов ${ }^{18}$. Сэр Роберт Дормер, важнейший человек в своем графстве, славный гостеприимством, был любим и почитаем соседями. Король Генрих VIII ${ }^{19}$ назначил его казначеем армии, с которой отправился под Монтрей во Франции ${ }^{20}$. Он был настолько любим людьми, что король, ценя его достоинства и доблесть, желал видеть его при дворе. Сэр Роберт, однако, добровольно вернулся в Англию и удалился в свое поместье. Он был счастлив жить среди соседей, как и его предки до него. Ибо в те времена люди, славные гостеприимством, избегали важных постов. Другими причинами его отсутствия при дворе были, сначала власть и гордыня тех, кто отдавал приказы, а затем - безумие короля, усомнившегося в законности своего брака с доброй и добродетельной супругой Екатериной $^{21}$. Дело обернулось к худшему, и добрые католики сокрушались, ибо король вышел из повиновения церкви Господней и жестоко преследовал тех, кто остался ей верен. Наш же добрый рыцарь показал свое рвение к истинной вере Господней. Когда он понял, к чему ведет король в парламенте, руководствуясь своими страстями (умерить которые или даже возразить грозило полным разорением), то всеми средствами стал избегать избрания в парламент. Будучи избранным в качестве рыцаря от своего графства, он отказался и передал полномочия другому, убедив графство, что так будет лучше для всех ${ }^{22}$. А когда король актом парламента за-

17 Семья НьюАигейт (выходцы и Саффолка) владела манором ХарфилА (сейчас - в черте Лонаона) с 1440-х гг. Ажон НьюАигейт (роА. ок. 1460), о котором илет речь, вероятно, второй владелец манора.

18 Амфимлис, Аочь Ажона Невимла и Энн Мейблторп, преАставительница млаАшей минии семьи Невим (из Ноттинэмшира).

19 Генрих VIII Tюдор (1491-1547), король Англии в 1509-1547 гг.

20 Войска императора Карла V и короля Генриха VIII осаждали Монтрей в 1537 г., в результате город был почти полностью разрушен.

21 Первая жена Генриха VIII, Екатерина Арагонская (1485-1536). Их брак был аннулирован архиепископом Кентерберийским Кранмером в 1533 г.

22 Сэр Роберт Аормер был избран в парламент 1529 г., и нет сведений о том, что он отказался от места в палате. Возможно, его отказ относится к 1532 г., когАа в графстве выбирали замену сэру Эндрю Виндзору, получившему баронский титул (и, соответственно, мишившемуся права избираться в нижнюю палату парламента). 


\section{Генри Клиффорд. Жизнеописание леди Джейн Дормер}

брал себе монастырские земли, то, чтобы сделать это более приемлемым и получить одобрение подданных этому нехристианскому поступку, раздал ${ }^{23}$ эти земли многим, или продал их за бесценок по отношению к настоящей цене, и предложил влиятельным в своих графствах дворянам по очень низким ценам, по сути, заставив их приобрести земли. Король поступил так, и отказаться или избегнуть покупки означало быть заподозренным в неподчинении ему или этому акту; в их верности королю могли усомниться. Наш рыцарь всеми способами старался избежать покупки тех земель, которые некогда были отданы Господу.

Когда это заметили приближенные короля, они сообщили ему, чтобы разжечь его гнев против сэра Роберта Дормера, тем самым подвергнув риску его жизнь и имущество. По этой причине сэр Роберт, поддавшись на уговоры друзей, был принужден купить Эбботс Астон $^{24}$, манор близ его дома. Как прежде монастырь, его дом стал убежищем и приютом для всех несчастных и гонимых католиков, священников и прочих, лишившихся приходов, лишь бы не подчиняться неслыханной тирании христианского государя.

Творя добрые дела своим щедрым гостеприимством, он провел годы правления короля Эдуарда ${ }^{25}$, и никакими средствами - ни требованиями, ни угрозами, или иными посулами нельзя было его заставить подчиниться незаконным желаниям тех, кто правил при короле-ребенке, и льстить им. У сына сэра Роберта было только две дочери, леди Джейн и ее сестра ${ }^{26}$, которых тогда считали наследницами его больших владений (их отец девять лет вдовствовал) ${ }^{27}$, и величайшие люди страны искали их руки для своих отпрысков. Но хотя старый и опытный рыцарь и делал вид, что укрывается в тени их величия, ибо тогда власть их

23 В тексте здесь: "сэр Роберт разАа^", но это - явная ошибка.

24 Астон Эбботс, манор в Аолине Эйлсбери (Бакингэмшир), ряАом с Уингом - манором Аормеров.

25 ЭАуара VI (1536-1553), король Англии в 1546-1553 гг.

26 Энн Аормер (1535-1603), старшая Аочь сэра Уильяма Аормера, с 1558 г. - жена морда Уолтера Хангерфорда (ум. 1596). С 1568 г. жила отАельно от мужа, в 1571 г. уехала из Англии в Аувен.

27 Первая жена сэра Уильяма Аормера умерла в 1542 г., а второй раз он женился ок. 1550 г. 
была велика, он опасался, что падение забравшихся высоко будет стремительным, или же им выпадут иные несчастья из-за безбожной гордыни и пренебрежения служению Господу, и поэтому отказался от их предложений, предпочтя видеть молодых дам женами добрых христиан, а не вельмож, запятнанных нечестивыми делами. Поэтому, когда герцог Нортумберленд ${ }^{28}$ приехал однажды к нему, чтобы предложить брак с одним из сыновей $^{29}$ и сделать самого сэра Роберта (уважаемого в графстве) сторонником своих планов, он так и не сумел его убедить.

Добрый рыцарь, посвятивший жизнь добрым делам, ревностный к славе Господней, перешел в вечную жизнь в 1552 г., оставив вдову, леди Джейн, с которой прожил сорок лет. Именно она была воспитательницей внучки, леди Джейн, и благороднее по добродетели и святости жизни, нежели по крови, хотя и происходила от Невиллов из королевского дома Ланкастеров ${ }^{30}$. Она была внучкой сэра Джона Невилла, так как ее мать приходилась ему дочерью и наследницей ${ }^{31}$, и, таким образом, происходила от Томаса Невилла ${ }^{32}$ и его жены Энн ${ }^{33}$. Последняя же была дочерью $^{34}$ Джона Холланда, герцога Эксетера ${ }^{35}$ и его супруги Элизабет $^{36}$, дочери Джона Гонта ${ }^{37}$.

28 Ажон АаАли, герцог Нортумберлена (1504-1553), в 1550-1553 гг. ^орА-председатель королевского совета, фактический правитель страны.

29 От брака с Ажейн ГилфорА у герцога Нортумберленда было шесть сыновей.

30 ПреАки леАи Ажейн Аормер (УрожА. НьюАигейт) происхоАили от Аругой ветви семьи Невимл и не состояли в роАстве с королевсКой Аинастией. См. примеч. 18.

31 Сэр Ажон Невимм (ум. 1516), отец Амфимлис НьюАигейт, принаАлежал к семье Невимлов из Ромсттона (Норхэмптоншир). КлиффорА перепутал его с лорАом Ажоном Невимлом (ум. 1461), внуком графа Уэстморленаа.

32 Томас Невиял, отец сэра Ажона Невимла, был женат на Изабел Бабингтон. Клиффора зАесь "соеАинил" Аве разные линии семьи Невилл.

33 Леди Энн Хомлана (ум.1486), Аочь Ажона Хомманда, 2-го герцога Эксетера (1395-1447), и Энн СтаффорА (ум. 1432) была женой ^орАа Ажона Невимла (ум. 1461) (см. примеч. 31). ЕАинственным ребенком от этого брака был Ральф Невилм, 3-й граф Уэстморлена (1456-1499).

34 Внучкой. Отец леди Энн, Ажон ХомманА, 2-й герцог Эксетер, был вторым сыном и тезкой того АЖона Хомланаа, которого зАесь имеет в виду автор (см. слеА. примеч.) 
Матерью Джейн Дормер была леди Мэри Сидни ${ }^{38}$, старшая дочь сэра Уильяма Сидни ${ }^{39}$, наставника и лорда-камергера принца Эдуарда в годы царствования его отца, короля Генриха VIII, и одного из наследников Чарльза Брендона, герцога Саффолка, приходившегося ему двоюродным братом ${ }^{40}$.

Ее братом был сэр Генри Сидни ${ }^{41}$, супруг Мэри, дочери герцога Нортумберленда ${ }^{42}$, лорд-депутат в Ирландии на протяжении восьми лет. Его дочерью была графиня Пемброк, мать ${ }^{43}$ сэра Филиппа Сидни ${ }^{44}$.

Вторая из сестер сэра Генри вышла замуж за отца лорда Харингтона $^{45}$, а третья - за сэра Уильяма Фицуильяма ${ }^{46}$. Младшая,

35 АЖон Хомана, 1-й герцог Эксетер, 1-й граф ХантингАон (ок.1352-1400), сводный брат короля РичарАа II, третий сын Томаса Хомланда, графа Кента.

36 Элизабет (ок. 1363-1426), Аочь герцога Ажона Аанкастера и его первой жены Бланш, герцогини ^анкастер.

37 Ажон Гонт (1340-1399), третий сын короля ЭАуарАа III, герцог Аанкастерский.

38 Мэри СиАни (ум. 1542), старшая Аочь сэра Уильяма СиАни и его жены Энн Пакенхэм.

39 Сэр Уимьям Сиани (1482?-1554), сын сэра Николаса Сидни и Энн БренАОН. Отличился в битве при ФлоААене (1513) и возведен за это в рыцарское Аостоинство. ОАин из телохранителей (squire of the body) короля Генриха VIII, позднее - наставник принца ЭАуарда и камергер его Авора.

40 Чарльз Брендон, герцог Саффолк (1484-1545), Аруг Аетства Генриха VIII и муж его сестры Марии, был сыном сэра Уильяма Брендона (1456-1485), павшего в битве при Босуорте знаменосца Генриха VII. Сестра сэра Уильяма Энн Брендон была матерью сэра Уильяма Сидни (см. преА. примеч.)

41 Сэр Генри Сидни (1529-1586), сын сэра Уильяма Сидни и Энн Пакенхэм. Ажентльмен королевской опочивальни при ЭдуарАе VI. ЛорА-Аепутат (королевский наместник) в Ирландии в 1561-1565, 1571-1578 гг.; член Тайного совета с 1579 г.

42 Мэри АаАли (ок. 1535-1586), старшая Аочь Ажона АаАли, герцога НортумберленАа, и Ажейн ГилфорА.

43 Ошибка: Мэри Сидни (1561-1621), супруга Генри Герберта, 2-го графа Пемброка - не мать, а сестра сэра Филиппа Сидни и Аочь сэра Генри СиАни и Мэри АаАли.

44 Сэр ФИлипп СиАни (1554-1586), елизаветинский приАворный и поэт, старший сын сэра Генри СиАни и Мэри АаАли.

45 Люси СиАни, с 1539 г. жена сэра Ажеймс Харингтона (1511-1592) из Экстон-Хомла (РатленА). Их старший сын, Ажон Харингтон (1540-1613), получил титул барона в 1603 г. 
Фрэнсис, стала женой графа Сассекса ${ }^{47}$, лорда-камергера королевы Елизаветы ${ }^{48}$, и основала колледж Сидни Сассекс в Кембридже $\mathrm{e}^{49}$. Были и еще две сестры, оставшиеся незамужними ${ }^{50}$ обе служили леди Марии ${ }^{51}$ прежде, чем она стала королевой, и были любимы ею за редкую добродетель и рвение к католической вере.

У сэра Уильяма Дормера ${ }^{52}$ от первой жены были только две дочери - Джейн, героиня этих мемуаров, и Энн, супруга лорда Хангерфорда. От второй жены ${ }^{53}$ у него был сын и три дочери. Сын, нынешний лорд Дормер ${ }^{54}$, женился на Элизабет ${ }^{55}$, дочери Энтони, виконта Монтегю ${ }^{56}$, и его жены Магдален ${ }^{57}$, дочери лорда Дейкра Северного ${ }^{58}$, породнившись благодаря этому со многими знатными семьями 59 .

46 Энн СиАни (ум. 1602), с 1543 г. жена сэра Уильяма Фицуильяма (15261599),в 1571-1575 гг. - лорда-депутата в Ирландии.

47 Фрэнсис Сияни (1531-1589), с 1555 г. жена Томаса Рэдклифа, 3-го графа Сассекса (1525-1583), лорда-камергера королевы Елизаветы I.

48 Елизавета I (1533-1603), королева Англии в 1558-1603 гг.

49 Комеаж Сидни Сассекс был основан в 1596 г. на средства, завещанные КембриАжскому университету графиней Сассекс (отсюда и его название).

50 Мейбл и Элизабет СиАни, фрейлины принцессы Марии Тюдор в нач. 1550-х гг.

51 Мария I (1516-1558), королева Англии в 1553-1558 гг.

52 Сэр Уильям Аормер (ок. 1514-1575), еАинственный сын Роберта Аормера и Ажейн НьюАигейт.

53 Ок. 1550 г. сэр Уильям Аормер женился вторым браком на Аороти Кэтсби (ум. 1613), дочери сэра Энтони Кэтсби из Уистона и Изабел Пигоп. После смерти мужа леди Аороти вышла замуж за сэра Уильяма Пелэма (1528-1587), верховного судью Ирландии.

54 Роберт Аормер (1551-1616), с 1615 г. - барон Аормер из Уинга.

55 Элизабет, леАи Аормер (урожА. Браун, ум.1631).

56 Энтони Браун, 1-й виконт Монтегю (1528-1592), сын сэра Энтони Брауна и Агнес ГейАж, член Тайного совета Марии I, при Елизавете - ^орАлейтенант графств Сарри и Сассекс.

57 Вторая жена виконта Монтегю, МагАален Аейкр (1538-1608), Аочь Уильяма Аейкра, 3-го барона Гилсленда и Грейстока, и Элизабет Тэлбот, Аочери графа Шрусбери.

58 Уильям Аейкр, 3-й барон ГилсленА и Грейсток (ок. 1493-1563), сын Томаса Аейкра, 2-го барона Гилсленда, и Элизабет Грейсток.

59 Монтегю и Аейкры приходились родственниками знатнейшим семьям Англии, включая практически всю северную знать - графов Нортумбер- 


\section{Генри Клиффорд. Жизнеописание леди Джейн Дормер}

Старшая дочь сэра Уильяма от второй жены ${ }^{60}$ вышла замуж за сына и наследника виконта Монтегю ${ }^{61}$ и является матерью Энтони, нынешнего виконта $^{62}$, знатного и ревностного в католической вере. Вторая дочь, Кэтрин, вышла замуж за лорда Сен-т-Джона из Блет$\mathrm{co}^{63}$, а младшая, Маргарет - за сэра Генри Констебла Северного ${ }^{64}$, джентльмена из старого и знатного рода. Его сын теперь - виконт Данбар $^{65}$ и женат ${ }^{66}$ на сестре графини Ратленд ${ }^{67}$.

\section{Глава II}

\section{О ее младенчестве и первых годах. Жизнь отца Себастиана Ньюдигейта, мученика}

Джейн Дормер родилась в доме деда, в Этропе ${ }^{68}$ неподалеку от Эйлсбери в графстве Бакингэм, 6 января 1638 г., в воскресенье и праздник Богоявления, предсказав тем самым вои взрослые добродетели, ибо явилась в мир, когда христиане радовались рождеству нашего Господа.

При крещении она была названа Джейн в честь бабушки, а насколько подходило ей это имя, означающее «благодать», станет ясно из дальнейшего рассказа о ее жизни. Когда она научилась говорить, осознавать и понимать свои обязанности, проявились и ее природные задатки. Она была сообразительной, легко

ленАОв (Перси), УэстморленАОв (Невимлов), КамберленАОв (КлиффорАОв), Шрусбери (Тэлботов) и ЭренАелов (Фицаланов и Ховардов).

60 Мэри Аормер (ум. 1637), жена 1)сэра Энтони Брауна (см. слеА. примеч.); 2)сэра ЭАмунда Ювдейла (ум. 1606); 3)сэра Томаса Ажерарда (ум. 1621).

61 Сэр Энтони Браун (1552-1592), старший сын 1-го виконта Монтегю от его первого брака с Ажейн Редклиф (1532-1552).

62 Энтони Мария Браун (1574-1629), 2-й виконт Монтегю.

63 Кэтрин Аормер (ум. 1615). Ок. 1575 г. вышла замуж за Ажона СентАжона, 2-го барона Сент-Ажона из Блетсо (ум. 1596).

64 Маргарет Аормер (ум. 1637). Ок. 1575 г. стала женой сэра Генри Констебла из Бертон Констебл (ок. 1551-1607).

65 Генри Констебл (1582-1645), 1-й виконт Аанбар с 1620 г.

66 Женой виконта была Мэри Тафтон (ум. 1659), дочь сэра Ажона Тафтона и Кристиан Браун.

67 Сесили Тафтон, старшая Аочь сэра Ажона Тафтона и Кристиан Браун, вторая жена Фрэнсиса Мэннерса, 6-го графа Ратленда (1578-1632).

68 Сейчас - Эйтроп в приходе УоААсон (Бакингэмшир). 
подчинялась правилам, была послушной, смиренной, уважительной к старшим, щедрой, как то подобало ее положению, так что казалась ребенком только по годам. Ее очень любили слуги и дамы, проживавшие в доме бабушки (многие из них были благородного происхождения; родители отправили их туда, чтобы они научились хорошему поведению и добродетели), и все эти знаки - такие добрые качества в столь юном возрасте, и такое прекрасное поведение - давали основание надеяться на соответствующие последствия позднее. Она была так послушна по отношению к родителям и так покорна наставнице, что в этом ясно проявлялся ее добрый нрав и удивительная почтительность. Она спешила преклонить колени, перекреститься, выучить молитвы, любила ходить в часовню, держать в руке молитвенник и четки, и радовалась всему священному. Когда Джейн исполнилось четыре года, Господу было угодно забрать ее мать с этого света, так что девочка еще в раннем детстве познала бедствия и переменчивость земного счастья, понеся огромную потерю в столь нежном возрасте. Бабушка взяла на себя обязанности по воспитанию девочки, и была она дамой редкого достоинства; подобных ей мало. Я расскажу немного о ее жизни и деяниях.

Леди Джейн, дочь Джона Ньюдигейта, вышла замуж за сэра Роберта Дормера в 1512 г. От этого брака родился единственный сын, сэр Уильям. До свадьбы она была образцом сдержанности и набожности; как жена - скромности, рассудительности и милосердия; а как вдова - терпения, благочестия и молитвенного подвига. Она всегда была верным другом; врагом тщеславия, смиренной, строгой к себе, исполненной рвения к Богу, жалости и сострадания к бедным, всегда милостивой и щедрой по отношению к соседям и арендаторам. Если кто из них заболевал, она всегда заботилась о них и посылала им яства и все необходимое. Она не просто посылала к ним каждый день, но и сама их посещала и помогала им в трудностях, особенно же - женщинам в родах. Своим присутствием она утешала самых бедных соседей и помогала им щедрой рукой.

Привязанность, с какой она почитала своего мужа и служила ему, была столь сильной, целомудренной и верной, что, как она сама утверждала, если бы он скончался в самый день их сва- 
дьбы, они никогда не вышла бы замуж снова. Она была столь рассудительной, что он доверил ей управление домом и поместьем, и она занималась этим всю жизнь с большой осмотрительностью и умеренностью. Она воспитала сына богобоязненным, держала в порядке всю семью, заведовала слугами, заботясь о том, чтобы они выполняли свои обязанности, так что казалось: она имела перед глазами в качестве примера «добродетельную жену», о которой говорил царь Соломон ${ }^{69}$. Она всегда приглядывала за служанками, следя за тем, чтобы они оставались дома, были скромными, стыдливыми и честного поведения. Вся ее жизнь была похвалой ее памяти. Все вокруг видели милостыню, подаваемую ею бедным; ее щедрость к священникам, монахам и другим несчастным, страдавшим от нечестивых гонений нашего времени; ее исполненные христианского рвения советы и наставления родственникам и друзьям придерживаться католической веры; и ее решимость убрать с их пути препятствия, которые могли бы ослабить их верность. Служившим ей женщинам предоставлялось достойной приданое, чтобы одни могли выйти замуж, а другие уйти в монастырь. Здесь же стоит отметить ее обычную щедрость к церкви во имя лучшей службы Богу; усилия ее и ее дам, расшивавших облачения, алтарные покровы и другие украшения богослужения; ее преданность и рвение к католической религии во время схизмы и отступничества, проявлявшиеся в том, что она содержала священников не только для своего дома, но и для блага и утешения всех соседей; ее ненависть к ереси; часы, проведенные ею в молитве и созерцании; ее труды, ее слова - все это вместе служит ей хвалой и хранит ее память.

Брат этой леди, Себастиан Ньюдигейт ${ }^{70}$, был высокопоставленным дворянином, служившим в Опочивальне короля Генриха

69 Притч. 31: 10-31.

70 Себастиан НьюАигейт (1500-1535), 7-й сын Ажона НьюАигейта из Харфилда и Амфимлис Невимл. ПриАворный, Ажентльмен королевской опочивальни при Генрихе VIII. Стал послушником лонАонской обители картузианцев не ранее 1526 г.; в 1531 г. рукоположен в диаконы, позднее - в священники (Аата неизвестна). В числе Аругих монахов отказался принести королю присягу как главе церкви Англии; был признан виновным в государственной измене и казнен. Причислен к мику блаженных католической церкви в 1886 г. 
VIII и испытывавшим его благосклонность. Этот король, поддавшись своим плотским страстям, соскучился со своей добродетельной женой, и стал влюбляться в других. Тогда добрая леди Дормер, опасаясь, как бы дурной пример великого короля не сбил ее брата с пути истинного, пригласила его к себе в дом (располагавшейся в одном дне пути от Лондона) и говорила с ним о порочности двора; о том, какие слухи ходят в графстве о распутности придворных; и о дурном примере короля, отвергшего такую знаменитую своими знатностью и добродетелями даму, какой была королева ${ }^{71}$. Леди Джейн посоветовала брату не забывать о мирских соблазнах и уловках дьявола; помнить об обязанностях христианина; и не запятнать своей души и чести заразой греха, как то случилось с его могущественным повелителем. В своем ответе брат оправдывал короля, своего господина, говоря, что слухи и мнение сестры о короле хуже, чем он того заслужил; но если король и впрямь окажется таким дурным, как о нем думают и говорят, то, обещал Себастиан сестре, он не забудет ее советов. Она же сказала, что ему стоит запомнить их и поступить согласно им. «Я так и сделаю», сказал он. «Этого я и боюсь», сказала она. После этих слов, немного помолчав и опустив голову на руку, он ответил: «Сестра, чтобы ты сказала, если бы следующим известием обо мне стала новость о моем пострижении в монахи в картузианской обители?». «Монах!», сказала она: «Боюсь, что скорее увижу тебя повешенным». (Через несколько лет она увидела и то, и другое). «Молю Бога, чтобы он сохранил тебя добрым христианином; такое совершенство - для людей, сделанных из иного металла, нежели распутные придворные». Улыбнувшись, брат простился с ней и вернулся ко двору.

Король продолжал прожигать жизнь в роскоши, назначая на должности, причем самые высокие, испорченных и распутных людей, льстивших ему в его порочных и жестоких устремлениях, унижая и смещая достойных и добродетельных. Увидев все это, в горе и смятении Себастиан, понимая, какими ужасными буря-

71 Имеется в виду первая жена Генриха VIII Екатерина Арагонская. УхоА НьюАигейта в монастырь приходится на то же время, что и начало ухаживания короля за Анной Болейн. 


\section{Генри Клиффорд. Жизнеописание леди Джейн Дормер}

ми и бедствиями грозят эти поступки короля всему королевству, и, вспомнив о разговоре с сестрой, решился высвободиться из уз двора и мирских опасностей и, пока не поздно, найти себе более безопасную гавань. Его не удержали ни должность при дворе, ни благосклонность короля, ни надежды на высокие назначения. С решимостью он отверг все это и принял постриг у картузианцев в лондонской обители; вступив в орден, который в Англии особенно почитали.

Когда сестра об этом узнала, она немало подивилась такой внезапной перемене в брате и сначала сочла ее заблуждением и дьявольским искушением, вознесшим брата так высоко, чтобы потом погрузить его в отчаяние. Ибо такая резкая перемена: от утонченности и места высоких устремлений и свободной беседы к строгости, презрению к людской славе, созерцанию, суровому молчанию и вечному затвору - порождала в ней эти страхи. Хотя по своим наклонностям он был не из худших, она считала его не лучше других придворных доброй репутации и даже не мечтала о таком совершенстве, чтобы ее брат обратился к жизни, отличной от той, в какой был воспитан; ибо всю свою жизнь он не мог переварить рыбу, а если ел ее, то выблевывал обратно. А монахи этого ордена никогда не ели мяса.

Рассудив так, она решила поехать в Лондон, чтобы увидеться с братом и высказать свое мнение приору; поэтому она пустилась в дорогу и приехала в Чартерхаус. Там она пожелала поговорить с отцом приором $^{72}$. Тот вышел к ней и, после должных приветствий, выслушал ее суждение о брате. Она посоветовала приору хорошенько подумать прежде, чем принимать брата в свой орден. Ибо ей казалось маловероятным, чтобы человек, вплоть до того времени проводивший жизнь в мирских развлечениях, подошел бы для столь строгого и сурового ордена. Приор ответил: «Добрая леди, слава Богу, он нам подходит», и сказал, чтобы она об этом не беспокоилась. Ее брат уже оставил юность позади и стал рассудительным человеком; он хорошо обдумал то, за что взялся, и уже предоставил достаточно доказательств того, что к монашеской жизни его побудила божественная благодать и привела его в этот

72 Уимьям Тинбиг, приор мондонских картузианцев в 1501-1529 гг. 
орден; и что из хорошего придворного он точно станет замечательным картузианцем. «Если дело обстоит так», ответила она, «благословен будь Господь и день, в который родился тот, кто сделал столь мудрый выбор, вопреки моему мнению. Могу сказать, что ему выпала счастливая доля».

Тогда приор приказал позвать брата Себастиана; он пришел к сестре, а та от слез не могла говорить. Ее не столько растрогали изменение его облика и облачения, сколько изумили его жесты, сдержанная речь, суровое смирение и скромность, он принизил себя так, как если бы всю жизнь провел в монастыре. Тут она успокоилась, ибо не могла желать большего; так рассказывала она сама. Расчувствовавшись от этой нежданной радости, она распрощалась с отцом приором и братом-послушником, вверив Всемогущему Богу его пребывание на этой стезе, а ее саму и родственников - его молитвам. Достойный Себастиан настолько продвинулся в своих молитвах и ученых занятиях, что был рукоположен в священники.

Король же, ослепленный своими плотскими страстями, рассорился с апостольским престолом, не дававшим разрешения на его развод ${ }^{73}$. Он пошел на полный разрыв, отрекшись от повиновения ему, оторвав себя и свое королевство от единства католической веры и объявив изменой признание подчинения апостольскому Римскому престолу ${ }^{74}$. Святость жизни теперь считали опасной; монашествующих преследовали, добрые люди страдали, а в делах религии совершались неразумные и несправедливые деяния. Когда это поняли благочестивые и добродетельные мужи, а именно, отцы-картузианцы, они сокрушались о злобе и бедствиях своего времени (которые, не останавливаясь, распространялись все дальше); и ожидали, что вскоре бедствия выпадут и на их долю. Ибо, когда король издал нечестивый и святотат-

73 Аело о расторжении (точнее, аннулировании) брака Генриха VIII и Екатерины Арагонской рассматривалось в 1527-1533 гг. В конце концов, не надеясь на благоприятный исход в Риме, Генрих VIII решился на разрыв с Папским престолом. Его первый брак был аннулирован архиепископом Кентерберийским Томасом Кранмером в 1533 г.

74 Имеется в виду Акт о Королевской Супрематии 1534 г., признавший короля главой церкви Англии. 
ственный закон, приказав всем признать под присягой, что он глава церкви в своих владениях (закон, ранее неслыханный в христианских государствах $)^{75}$, то, предполагая, что мудрые и знающие люди сочтут его жестоким, он посовещался с советниками и решил сначала привлечь на свою сторону тех, кто славился добродетельной жизнью или ученостью. Если бы он сумел завоевать тех, к кому были прикованы взгляды других, остальных легче было бы привести в подчинение ложному закону.

Следуя этому плану, король узнал на опыте, что щедрые обещания и ласковые убеждения не действуют на людей, верно служащих Богу, и решился принудить их силой и жестокостью. Тут его нечестивые министры-святотатцы взялись прежде всех за отцов лондонской обители картузианцев. В ней по делам ордена тогда находились два других приора картузианцев, а именно, отец Роберт Лоуренс, приор обители в Беверли ${ }^{76}$, отец Августин Уэбстер ${ }^{77}$, приор монастыря в Хексеме ${ }^{78}$, и лондонский приор, отец Джон Хаутон $^{79}$. Все они были достойными людьми, известными рассуди-

75 Акт о королевской Супрематии 1534 г. предписывал англичанам принести королю присягу как главе национальной церкви.

76 Роберт Аоуренс (ум. 1535), выпускник Кембриджского университета, приор картузианского монастыря в Бивейле (Ноотингэмшир) в 1531-1535 гг. Отказался принести присягу Генриху VIII как главе церкви, был признан виновным в измене и казнен в ^ондоне 5 мая 1535 г. Причислен к лику блаженных католической церкви в 1886 г., канонизирован в 1970 г.

77 Августин Уэбстер (ум. 1535), выпускник КембриАжского университета, монах картузианской обители в Шине (близ ^онАона), в 1531-1535 гг. приор монастыря в Эксхолме. Отказался принести присягу Генриху VIII как главе церкви Англии, был признан виновным в измене и казнен в ^ондоне 5 мая 1535 г. Причислен к лику блаженных католической церкви в 1886 г., канонизирован в 1970 г.

78 Сейчас-Эксхолм в ^инкольншире.

79 Ажон Хаутон (ок. 1486-1535), выпускник Кембриджского университета, с 1516 г. монах ^ондонского монастыря картузианцев; в 1531 г. был избран приором обители ордена в Бивейле, но через несколько месяцев вернулся в лондонский монастырь, когАа его избрали в ней приором. В Бивейле его преемником стал ^оуренс (см. выше, примеч. 72). Отказался принести присягу Генриху VIII как главе церкви Англии, был признан виновным в измене и казнен в Лондоне 5 мая 1535 г. Причислен к лику блаженных католической церкви в 1886 г., канонизирован в 1970 г. 
тельностью, добродетелью и ученостью. Обратившись к трем приорам, [министры] сначала показали им опубликованный эдикт о королевской супрематии и предложили признать его письменной клятвой. Досточтимые отцы ответили: «странная и неслыханная просьба», ибо они никогда не встречали в книгах подобного примера в церкви Господней; а ее в духовных делах следует слушать первой, как супругу Господа нашего Иисуса Христа, руководимую и направляемую Его Святым Духом; этому же должны быть подчинены все человеческие законы. Им ответил сэр Томас Кромвель ${ }^{80}$ (бывший генеральным викарием короля в духовных делах и главой комиссии в этом деле), оскорбляя их последними словами, называя негодяями и изменниками из-за отказа, и заставляя их поклясться, четко и ясно, во всем, что требовалось, вне зависимости от того, дозволяет ли это божественный закон, или не дозволяет. Отцы отказались, сказав, «что они - священники и сыновья католической церкви и обязаны повиноваться ее учению и предписаниям». Нечестивый викарий ответил: «мне нет дела до вашей церкви; если вы не подчинитесь закону короля, я покараю вас и ваш орден и не остановлюсь, пока не уничтожу вас всех». Но эти добрые отцы предпочли скорее рассердить короля, нежели Бога, и их, с двумя другими священниками ${ }^{81}$, доставили в тюрьму. Оттуда через пять дней, после жестокого обращения и нескольких допросов их привели в суд и приговорили к смерти. 5 мая 1535 г. их, в их монашеском облачении, приволокли к Тайберну ${ }^{82}$ и там повесили, вынули из

80 Томас Кромвель (ок. 1485-1540), юрист, советник кардинала Уолси в 15161530 гг., в 1530-1540 гг. - фаворит Генриха VIII, канциер казначейства (1533-1540), государственный секретарь (1534-1540), лорА-хранитель королевской печати (1536-1540), великий камергер (1540), граф Эссекс (с апреля 1540 г.). Аишился благоскионности короля в 1540 г. из-за утроенного им и оказавшегося неудачным брака короля с Анной Клевской. Был арестован, объявлен вне закона актом парламента и казнен 28 июля 1540 г.

81 Вместе с приорами-картузианцами 4 мая 1535 г. были казнены РичарА Рейнолас (1492-1535), монах-бригетинец из Сионского монастыря (в РичмоАе, близ АонАОна) и АЖон Хейл (Ум. 1535), прихоАский священник из Ислуорта. Оба были причислены к лику блаженных католической церкви в 1886 г., канонизированы в 1970 г.

82 Тайберн (сейчас находится близ Марбл Арч [“Мраморной Арки»] в Аондоне) - в средние века небольшая Аеревушка, в которой сходились Аве римские Аороги; место казней Аондонских преступников с конца XII в. АО 1783 г. 
петель еще живыми и четвертовали, а останки вывесили на городских воротах, а части тела приора Лондонского — на воротах его собственного монастыря.

Через три недели, 25 мая, поняв, что жестокое обращение с указанными отцами вовсе не убавила храбрости и решимости остальных, свирепые законники ${ }^{83}$ схватили еще троих в лондонской обители: отца Себастиана Ньюдигейта, отца Хамфри Миддлмора, викария конвента ${ }^{84}$, и отца Уильяма Эксмью ${ }^{85}$, прокуратора; оба они хорошо знали греческий и латынь и пользовались уважением в своем ордене. Хотя они не были старыми, но держались строго и почтительно, и вели серьезные и душеполезные беседы. Троих отцов выволокли из клуатра с бесчеловечной жестокостью и отправили в Маршалси ${ }^{86}$, где держали четырнадцать дней прикованными к столбам, стоя, с железными кольцами вокруг шеи, рук и ног. Такая жестокость должна была принудить их подчиниться воле короля и, если возможно, заставить их подписаться под законом о супрематии. Когда король убедился в их неколебимой верности [католичеству], он проявил особый интерес к отцу Себастиану и, переодевшись, отправился в тюрьму поговорить с ним. Король позвал его и объяснил: он питает к Себастиану такую сильную привязанность, что лично пришел навестить его, и посоветовал ему не губить себя добровольно,

83 Комиссию, состоявшую из юристов и богословов, возглавля^ Томас БеАимл (ум. 1537), королевский капемман и клерк Тайного Совета.

84 Хамфри МиААлмор (ум. 1535). Прокуратор ^ондонской обители кратузианцев; стал викарием обители после ареста приора Хаутона. Отказался принести присягу Генриху VIII как главе церкви Англии, был признан виновным в измене и казнен в Аондоне 19 июня 1535 г. Причислен к иику блаженных католической церкви в 1886 г.

85 Уильям Эксмью (ум. 1535), суб-приор, затем прокуратор мондонской обители картузианцев. Отказался принести присягу Генриху VIII как главе церкви Англии, был признан виновным в измене и казнен в ^ондоне 19 июня 1535 г. Причислен к лику блаженных католической церкви в 1886 г.

86 Маршалси - тюрьма, существовавшая в южном пригороде АонАона (Саутуорке) в 1373-1842 гг. В нее отправляли тех, кто Аолжен был предстать перед судом лорда-маршала (т.е., главы королевской свиты), или судом Королевской скамьи. В XVI в. в эту тюрьму часто отправляли католиков, обвиненных в нарушении законов о религии. 
зная предписанные законом кары, а также судьбу собратьев по ордену, пострадавших из-за отказа и неповиновения. Король напомнил Ньюдигейту о дарованных ему вознаграждениях; сказал, что неблагодарность уравняла бы его с теми, кто, как изменники, отказались подчиниться закону, в отличие от многих других монахов и всего дворянства; что такое упрямство не могло быть оправдано. Король сказал, что ему [Ньюдигейту] придется претерпеть великие мучения, если он станет упорствовать в своей глупости и не подчинится требованиям, так как он обязан повиноваться своему господину и королю и делать то, что тот прикажет; «если (сказал король) ты это сделаешь, то увидишь, что у меня есть и желание, и власть вознаградить тебя». Сильное искушение и весомые доводы.

Добрый отец ответил: «Я должен признать великой честью, которую я едва ли заслужил своей недостойностью, то обстоятельство, что Ваше Величество снизошли до посещения своего бедного слуги и монаха в столь неприглядном месте. Признаю, что получил немало милостей от Вашего Величества. Да вознаградит Вас Господь, о чем я каждый день прошу Царя Небесного. Покуда жив, я буду молиться о Вашем здравии и счастье, и о процветании вашего королевства. Я - монах и потому обязан говорить правду. Желание спасти душу, которую Господь наш Иисус Христос искупил ценой своей жизни и пролития Его драгоценной крови, охватило меня и указало на искушения и опасности мирской жизни, побудив меня удалиться от нее (иначе я бы погиб от своей недостойности) в гавань монашества. Здесь я, и все в нашем ордене, денно молятся Богу о Вашем здравии и благополучии, о том, чтобы Он оказывал Вам милость Свою и одарил Вас счастьем. Господь наш Иисус Христос - свидетель, что не презрение, упрямство, недовольство, желание бунта, или чей-либо совет заставляет меня не подчиниться закону или не принять предложенную клятву, но только лишь учение Святой церкви и закон божий, нарушить которые я не могу». Король не пожелал его больше слушать и ушел в ярости, осыпая его угрозами и проклятьями.

Через четырнадцать дней, в течение которых добрые отцы выносили эту жестокую пытку, их привели к лордам Тайного Совета, допросили по одному и снова потребовали признать новый закон о 


\section{Генри Клиффорд. Жизнеописание леди Джейн Дормер}

супрематии, который, как они сказали, отменил любую власть иностранцев. Ответ их был таков: «власть Церкви не может быть иностранной ни в одной христианской стране, а они никак не могут подчиниться тому, что не согласуется с божественным законом или противоречит учению нашей святой матери-церкви».

После допросов, посулов и угроз, видя, что они по-прежнему упорствуют, и их нельзя склонить к согласию, лорды отправили их узниками в лондонский Тауэр, и там они оставались восемь дней. Король находился там же и опять приступил к отцу Себастиану, но не с мягкими речами, а с угрозами и оскорблениями. Тем не менее, бесстрашный исповедник терпеливо выслушал его, сказав в ответ: «Будучи при дворе, я верно служил Вашему Величеству, и по-прежнему остаюсь вашим смиренным слугой даже в тюрьме и в оковах. Но в делах, относящихся к вере и к славе Господа нашего Иисуса Христа, учению католической церкви и спасению моей бедной души, Ваше Величество должны признать мою свободу». Король отвечал: «Ты считаешь себя мудрее и святее всех людей духовных и светских в моем королевстве?» Тот сказал: «Я - не судья другим и не считаю себя мудрым или святым, ибо мало во мне и того, и другого. Уверен я лишь в том, что вера, которую я исповедаю, не новая и новоизобретенная, но всегда считалась благочестивыми христианской и католической. Мы должны повиноваться Богу, а не человеку».

Получив такой решительный отпор, король не стал дальше рассуждать с ним, а назвал его изменником и, придя в страшную ярость, сказал ему, что и покарают его как изменника. Но ни уловки, ни запугивание не проникали в доблестную грудь, защищенную Духом Господним, остававшуюся недвижной, подобно скала, вспоминая божественный совет Псалмопевцу: «Не надейтесь на князей, на сына человеческого, в котором нет спасения» $^{87}$, а также бессмертные слова Маккавея, не побоявшегося сказать в лицо царю Антиоху: «не послушаем мы слов царя, но подчинимся закону божию, данному нам» ${ }^{88}$.

87 Пс 145:3

881 Мк 2:22. В Синодальном переводе: «Не послушаем мы слов царя, чтобы отступить нам от нашего богослужения вправо или влево". 
18 июня троих отцов привезли в Вестминстер на суд. Там им предъявили обвинение в измене за отказ подписаться и присягнуть королевской супрематии, снова допросили и задали вопрос, не согласятся ли они, наконец, показать свое повиновение, как все остальные подданные. Все они ответили, что в данном случае не могут, не станут и не должны этого делать, процитировав и сославшись на божественное Писание, отцов церкви, и священные установления, доказывающие, что ни один светский государь не может законно взять на себя управление церковью, каковое Царь царей и Господь Иисус Христос даровал только лишь Св. Петру и его преемникам. Они считают это заповедью Слова Божия, а значит: отказываться от этой веры или же противоречить ей есть дерзость и грех. Они были готовы обосновать это при помощи весомых и ученых доводов, если бы им позволили, показывая решимость и неколебимую верность учению. Не видя другой возможности, судьи применили против них законы и вверили их судьбу 12 присяжным, которые признали их виновными в измене. Однако прежде чем судья произнес им смертный приговор, он употребил множество доводов, уговаривая их, в конце концов, смягчиться и подчиниться, уверяя их, что подчинение дарует им милость короля, и призывая задуматься об утрате тех, кто мог бы послужить Господу и стране. Судья говорил, что они спешат к позорной смерти, упоминал горе друзей и унижение родных, в особенности он обращался к отцу Себастиану, напоминая ему о благородстве его крови, знатных друзьях в королевстве, долге по отношению к королю, которому он раньше служил, милости, от него полученные; призывал его одуматься и подчиниться, уверяя его, что еще есть время милости и прощению. Но никакие увещевания не действовали на сильные умы, устремленные к божественной любви. Монахи стремились лишь умереть за Него и пролить кровь за католическую веру. Они не придавали значения тщеславным мирским побуждениям и храбро и твердо ждали приговора, который был им дан таким образом. Они были признаны виновными в измене и должны были вернуться в место, откуда их привели. Оттуда же их должны были выволочь на место казни и повесить, затем перерезать верев- 
ку, вырвать внутренности, рассечь тела на четыре части и поместить их туда, куда укажет судья ${ }^{89}$.

Досточтимые отцы выслушали и приняли этот жестокий приговор, спокойно произнеся "Dei Gratias", благодаря Спасителя нашего Иисуса Христа, милостиво признавшего их достойными пострадать за Его веру и в защиту церкви. Так что их вернули в тюрьму, а на следующий день (19 июня) приговор привели в исполнение. Отцов вывели из тюрьмы, привязали к волокушам, которые потом лошади протащили по лондонским улицам до Тайберна - места казни. Достойное жалости зрелище - невинные монахи в своих облачениях, с которыми так обращаются за то, что они верны древней католической церкви, причем те, кто сами называют себя христианами.

Прибыв на место казни, они восславили Бога. Они терпеливо подчинялись всем приказам судейских, добровольно и с радостью отдавая свои тела жестокой и бесчеловечной смерти во имя веры Христовой и единства его святой обручницы-церкви. Никакие доводы (а их много приводили) не смогли изменить их мнения и заставить подчиниться закону короля. Отца Себастиана отвязали от волокуши, оставив веревку на шее, и поместили в телегу. Там он вверил себя молитвам помощников ${ }^{90}$; помолился за короля, прося Господа даровать ему здравие и долголетие, и призывая Его Величество позаботиться о своем спасении и о благе королевства, долгие годы процветавшего в христианской вере, единстве и в подчинении католической церкви Христовой. Он заявил о своей невиновности перед королем и миром, сказав, что его смерть - исповедание и защита католической церкви, и его судьи будут тому свидетелями. Приготовившись умереть, он произнес на латыни слова Псалма: «На Тебя, Господи, уповаю, да не постыжусь вовек», до стиха «В Твою руку предаю дух мой;

89 В тексте воспроизводится формула приговора, характерная Аля дел об измене. Приговоренных к смерти изменников вешали, вынимали из петли живыми, кастрировали их (о чем не упомянул КмиффорА), вырывали им внутренности, отрубали голову и конечности. В качестве милости монарх мог приказать повесить приговоренного до смерти и совершать все Аальнейшие Аействия с его трупом. Картузианцам такой милости оказано не было.

90 Тех, кто окружал его во время казни, т.е., палачей и судейских. 
Ты избавлял меня, Господи, Боже истины» ${ }^{91}$. Затем телегу сдвинули у него из-под ног, а он повис, но совсем ненадолго: его и двух других отцов сняли с виселицы еще живыми и немедленно взрезали им животы. Их внутренности бросили в огонь, отсекли им головы, рассекли тела на четыре части и выставили их на дорогах и на лондонских воротах. И при совершении этой жестокости по отношению к невинным была также совершена еще одна бесчеловечность: того, кого должны были казнить вторым, заставили стоять и смотреть на смерть и расчленение первого, а третий видел смерти обоих; страшное тиранство - заставить их смотреть, как предают смерти братьев.

Такова была суровая кончина и счастливый конец отца Себастиана, храброго дворянина, истинного монаха и славного мученика во имя Иисуса Христа. Он оказал великую честь своему роду и навсегда прославил семью. Ибо ничто не украшает дом герцогини (происходившей от великих государей) больше и не придает ее крови больше чести, нежели ее родственник и дядя, славный и знаменитый мученик, достойный монах, верный слуга Иисуса Христа. Он при первом же проявлении враждебности к католической вере в нашей стране доблестно выступил за нее и отдал кровь и жизнь на ее защиту.

Этот дворянин, как его мне описывали, был довольно высокого роста, хорошо сложен и пригож, с лицом живым и красивым. Он был храбр; вел себя доброжелательно, честно и скромно. Когда он стал монахом, эти черты его природы и воспитания усилились благодатью и благочестием, как было показано.

\section{Глава III}

\section{О бабушке Джейн Дормер. Она поступает на службу к принцессе Марии}

Старшая сестра этого славного мученика и была той добродетельной дамой, о которой мы здесь расскажем, а именно, бабушкой герцогини. Другая его сестра вышла замуж за сэра Лео-

91 Пс 30:2-6. 
нарда Чемберлейна из Оксфордшира ${ }^{92}$ и стала матерью леди Стонор $^{93}$, известной своим рвением к католической религии. Ее я мальчишкой видел в Оксфорде, когда она там предстала пред судьями из-за отказа посещать протестантские службы, на 23-м или 24-м году правления королевы Елизаветы ${ }^{94}$. Когда ее упрекнули за верность католической религии (что тогда каралось английскими законами), она ответила: «Я родилась, когда святую мессу почитали, и была воспитана в этой вере. Во времена короля Эдуарда правители от этого почитания отказались и осуждали его. При королеве Марии его восстановили со всеобщего одобрения, а теперь властям угодно сомневаться в тех, кто, подобно мне, продолжает исповедать католичество. Власти считают изменения, которые я видела своими собственными глазами, добрыми и похвальными. Пусть Ваши Лордства судят, так ли это. Я же придерживаюсь той веры, в какой родилась и была воспитана, и нахожу в ней лишь святость и великую добродетель, и так, по милости Божией, буду жить и умру». Такой ответ поразил судей, ибо произнесен был с большой уверенностью; они отпустили ее под обычный залог. Эта леди была известна редким благочестием и удивительным воздержанием, и до смерти оставалась вдовой.

Еще две сестры были монахинями; одна - аббатисой Сионского монастыря в Брентфорде (Миллдсекс) ${ }^{95}$. Эта община принадлежала ордену Св. Бригитты и до сих пор существует в Лиссабоне (Португалия), выехав из Англии вместе с герцогиней, когда та направлялась во Фландрию ${ }^{96}$. Там конвент пробыл не-

92 Женой сэра Леонарда Чемберлейна (1504-1561) из Вудстока (Оксфорашир) была Аороти НьюАигейт.

93 Сесили Чемберлейн, жена лорАа Фрэнсиса Стонора (ок. 1520-1564).

94 Т.е., в 1581 или 1582 гг.

95 Мэри НьюАигейт была монахиней Обители Сион, но не аббатисой. Последней аббатисой (Ао отьезаа из Англии в 1539 г.) была Элис Ажордан (в 1520-1539 гг.). Автор ошибся: главой монашеской общины была ее младшая сестра (см. примеч. 97).

96 Конвент бригеттинок, основанный в 1415 г. в королевском маноре Шин (Ричмона). В 1539 г. община эмигрировала в Нилерланды, а в 1553 г. вернулась. После отьезАа в 1559 г. монахини Аолгое время скитались от города к городу в Нияерландах и Северной Франции, а в 1594 г. осели в ^иссабоне. В 1861 г. община вернулась в Англию. 
сколько лет, до отъезда в Испанию. Другая сестра вступила в орден Св. Доминика ${ }^{97}$. Обе они служили примером строгой и святой жизни. Двое братьев были рыцарями на Родосе и принадлежали к ордену Св. Иоанна ${ }^{98}$. В 1522 г. Родос был осажден султаном Сулейманом ${ }^{99}$, а христианские рыцари этого ордена храбро защищались, и на этой войне оба брата отдали свои жизни.

Мудрость и добродетель бабушки Джейн Дормер ярко проявились в ее делах, например, в устройстве брака своего сына, сэра Уильяма. Когда она увидела испорченность властей в королевстве и в особенности тех, кто по рангу и достоинству должны были бы быть защитниками справедливости и веры, но действовали вопреки им, она пожелала устроить его брак с добродетельной дворянкой доброго нрава. Ее муж, сэр Роберт Дормер, согласился с ней и приказал ей все устроить прежде, чем о деле узнает король и вмешается в него своим приказом. Так как Уильям Дормер был их единственным ребенком и наследником больших владений, многие придворные хотели выдать за него замуж своих родственниц. Среди них был сэр Фрэнсис Брайан ${ }^{100}$, знаменитый фаворит короля, который хотел женить его на своей племяннице Джейн Сеймур ${ }^{101}$. Благодаря близости к королю влияние этого рыцаря было столь велико, что когда он начал обсуждать это дело с сэром Робертом Дормером, противостоять ему нужно было не только волей, но и хитроумием. Пока между ними велись переговоры, мать, презирая характер этого рыцаря, взяла своего сына и отправилась в Лондон, в дом сэра Уильяма Сидни, поскольку ранее уже сделала от имени сына предложение

97 Младшая Аочь, Сибил НьюАигейт (1509-после 1549) стала монахиней, а в 1534-1539 гг. приорессой конвента августинок (не Аоминиканок!) в Холиуэме (ШорАич, тогАа - пригороА ЛонАона).

98 Скорее всего, Чарльз (1493-1522) и Уильям (1495-1522) Ньюдигейты.

99 Сулейман I Великолепный (1494-1566), султан Османской империи в 1520-1566 гг.

100 Сэр Фрэнсис Брайан (ок. 1490-1550) - старший Аворянин опочивальни Генриха VIII, близкий Аруг короля.

101 Ажейн Сеймур (1506-1537), третья жена Генриха VIII, была не племянницей, а троюродной сестрой сэра Фрэнсиса Брайана: их бабушки по материнской линии (Элизабет Тилни и Энн Сай) - сводные сестры. 


\section{Генри Клиффорд. Жизнеописание леди Джейн Дормер}

леди Сидни, и та была им довольна. Эти две дамы устроили брак между сыном одной и старшей дочерью другой. Когда об этом узнал сэр Фрэнсис Брайан и понял, что его провели, он был весьма недоволен, но эта дама взяла всю вину на себя, уверив его: переговоры с леди Сидни она вела раньше, и не могла пойти на попятный. Пытаясь устроить брак своей племянницы, сэр Фрэнсис дал им понять, что девушка будет хорошо обеспечена. Ибо он, отвезя ее ко двору, устроил ее в свиту королевы Анны Болейн, где ее и заметил король, и из-за этого между королевой и ее фрейлиной было немало ссор. В конце концов, королеву Анну Болейн арестовали, приговорили и обезглавили за гнусную супружескую измену. На следующий же день король женился на леди Джейн Сеймур, и она родила ему сына ${ }^{102}$. Своим разумным и храбрым поступком леди Дормер показала любовь к благочестию и христианской вере, почтение к целомудрию и чести, женив сына на девушке доброй славы, и ни получение большого приданого, ни власть королевского фаворита, ни возможность завоевать себе влиятельного друга при дворе, ни надежды благодаря ему приобрести почести и богатство, ни страх последствий его враждебности не могли заставить ее женить сына на племяннице того, кто погубил свою веру и честь.

Когда король Генрих умер, и началось царствование короля-ребенка Эдуарда, католическую веру изгнали и запретили там, куда могло дотянуться правительство, а на ее место поставили ересь и схизму. Чтобы они лучше прижились, в королевстве принимали священников и монахов-отступников из разных стран, вместе с их женами, и ставили их проповедниками в университетах, предоставляя им учить ереси. Если же благочестивый или ученый католик возражал (как это делали многие) против учения этих заморских отступников, таких преследовали, заставляли замолчать, лишали приходов, отправляли в тюрьму или в изгнание. Добрая дама, бабушка герцогини Ферия, чей дом стал приютом гонимых, обеспечивала пропитание и безопас-

102 Генрих VIII обручился с Ажейн 20 мая 1536 г., на следующий Аень после казни Анны Болейн. СваАьба состоялась 30 мая, а 12 октября 1537 г. Ажейн родила принца ЭАуарда. 
ность их телам, а от них получала пищу для души для себя, своей семьи и соседей. Это заметила леди Мария, немало благоволившая ей и членам ее семьи; когда же она стала королевой и эта леди прибыла к ее двору, то Мария вспомнила ее гостеприимство и особо поблагодарила ее за щедрость, назвав хранительницей католической веры. Леди Дормер рекомендовала Ее Величеству нескольких из этих добрых людей, и королева приняла их в качестве своих капелланов, другим же дала епископства и прочие должности. Таковы были достойные люди, которым оказывала гостеприимство эта добрая леди.

Если я начну подробно рассказывать о щедрых деяниях этой дамы, мне придется потратить немало страниц. Будучи женой и вдовой и управляя домом в течение тридцати лет, она ежедневно раздавала милостыню и совершала добрые дела, что и подтвердилось событиями, случившимися в царствование короля Эдуарда, в ответ на ее гостеприимство и щедрость. Ибо многие невзлюбили эти странные перемены религии, а божественную литургию еще не утвердили (так как в течение пяти или шести лет все эти горячие головы не могли утвердить форму литургии, которая бы всем нравилась), и люди были также недовольны правительством $^{103}$. Великие лорды сговаривались, стараясь уничтожить друг друга. Многие из тех, кто имел власть и влияние в графствах, воспользовались обстоятельствами и присвоили земли, находившиеся в общинном пользовании и необходимые всем. Джентльмены низкого ранга, богатые и имевшие больше власти, нежели соседи, следуя примеру своих лордов, тоже взяли себе во владение поля и пастбища, которыми ранее пользовалась вся округа. Во многих местах люди сокрушались и жаловались на эти несправедливости, как они их называли, и, не надеясь получить защиту у властей, в некоторых графствах взяли дело в собственные руки, стремясь покарать тех, кто совершил злые дела; собравшись, мятежники взялись за оружие, угрожая этим злодеям. Мятежники разрушали все на своем пути, уничтожали

103 Речь идет о восстании июня 1549 г. против введения новой литургии, а также огораживаний общинных пастбищ. Оно охватило Аевон и Корнуом^, а также Бекингэмшир и ОксфорАшир. ЗАесь речь иАет о послеАних Авух графствах. 


\section{Генри Клиффорд. Жизнеописание леди Джейн Дормер}

изгороди, ломали заборы, засыпали канавы, грабили дома и совершали множество других преступлений, так что дворянам приходилось либо покидать свои дома, либо укреплять их и охранять с помощью соседей всеми силами, какие они только могли найти для защиты домов против этой ярости.

В дом к леди Дормер пришли многие люди всех сословий, из соседних деревень, с женами, детьми и лучшим из имущества; все они готовы были с оружием в руках защищать ее саму и ее дом. Добрая леди приветствовала их и благодарила, зная, что в такие мятежные времена закон и справедливость почитают мало, и укрепила свой дом, как смогла. Когда мятежники узнали об этом, и о запасах, сделанных ею для защиты, они отправили ей следующее послание: ее сиятельству не стоит опасаться, так как ее щедрость и добрые дела, известные всему графству, - достаточная защита для нее самой и ее семьи, прославленных гостеприимством и христианскими добродетелями. Они (по их словам) пришли не грабить и наносить ущерб, но вернуть общинам то, что ми принадлежало. Сильные и богатые люди несправедливо и не по совести забрали себе то, что принадлежало всем людям; именно в этих людей они целились, и именно они и должны ответить за свою жестокость и обиды. Как они и обещали, они прошли по ее землям, не нанеся другого ущерба, кроме потоптанной травы, и не совершив ни одного проступка против ее людей или имущества. В парках же и на землях дворян вокруг нее они многое разрушили и учинили много насилия.

Когда Господу было угодно забрать с этого света ее мужа, сэра Роберта Дормера, с которым они прожили около сорока лет, ее сын, сэр Уильям Дормер, был женат вторым браком ${ }^{104}$, после девятилетнего вдовства. От первой жены (как уже говорилось) у него было только две дочери, а от второй - сын (теперь - лорд Дормер), которому было пять месяцев, когда умер его дед. Став вдовой и освободившись от обязанностей жены, леди Дормер, по совету Св. Павла, обрела свободу служить Господу. В обоих со-

104 Сэр Уильям Аормер оваовел в 1542 г., а в 1550 или 1551 г. женился на Аороти Кейтсби (ум. 1613), дочери Энтони Кейтсби из Уистона, и Изабемм Пигот. 
стояниях она показала себя примером и зерцалом для всех благородных женщин. Будучи замужем (как сказано выше), она всегда старалась выполнять обязанности жены, любя и почитая мужа, держа дом в порядке, управляя семьей с похвальной осмотрительностью, воспитывая сына и внучек (потерявших свою мать) в добродетели; и в целом она вела себя как разумная, мудрая и рачительная дама и как любящая мать. Став вдовой, она отошла от мирских дел, хотя и продолжала в некоторой степени заботиться о поместьях сына. Ее вдовья доля, выделенная из его имущества, соответствовала ее рангу, и она хорошо ею управляла. Большую часть времени она проводила в молитве и благочестивых делах и неукоснительно (когда здоровье позволяло) присутствовала на литургии. Она трудилась для церкви и во благо тех, кто пребывал в нужде.

Вскоре после кончины ее мужа, сэра Роберта Дормера, умер король Эдуард ${ }^{105}$. Ему наследовала католическая правительница, королева Мария, которая без сражений и пролития крови победила герцога Нортумберленда, пытавшегося посадить на престол невестку, леди Джейн Грей ${ }^{106}$. В сумятице войны, начатой, чтобы

1056 июля 1553 г.

106 Ажейн Грей (1537-1554) - старшая Аочь Генри Грея, 1-го герцога Саффолка, и Фрэнсис Брендон, герцогини Саффолк, внучка и наследница Марии Тюдор, младшей сестры Генриха VIII. Парламентский акт о престолонаследии (1544) устанавливал порядок передачи престола в случае смерти принца ЭдуарАа, или отсутствия у него Аетей. Согласно акту, наследницами ЭАуарАа объявлялись его сестры Мария и Елизавета (хотя обе они считались незаконнорожАенными), а после них - дети Фрэнсис Брендон (исключив ее саму, а также всех потомков старшей сестры короля, Маргарет, т.е., шотландскую линию). Кроме того, акт о государственной измене (1547) объявля^ преступлением попытку изменить престолонаследие вопреки предписаниям акта 1544 г. Таким образом, в 1553 г. наследницей безАетного короля Эдуарда VI была его сестра, принцесса Мария. ОАнако она была католичкой, и, протестантские ^орды Совета во главе с герцогом Нортумберлендом с согласия короля попытамись обойти закон. Королевский патент от 21 июня 1553 г. объявлял наслеАницей престола леди Ажейн и ее Аетей от брака с ГилфорАом АаАли (1535-1554), сыном Нортумберленда. ЭАуарА VI скончался 6 июля 1553 г., но его смерть скрывали несколько Аней; 10 июля Ажейн была провозглашена королевой в ЛонАоне. ОАнако большинство английского Аворянства подАержало законную наслеАницу, Марию. КогАа Нортум- 
уничтожить истинную королеву и защитить узурпатора, сын нашей леди, сэр Уильям Дормер, созвал друзей и собрал силы во имя королевы Марии. Однажды он вместе с ними отправился в Эйлсбери, зная, что там будет со своими сторонниками граф Бедфорд ${ }^{107}$, желающий заставить графство Бакингэмшир объявить себя за леди Джейн. М-р Дормер, встретив его, прямо ему сказал: «Милорд, мы знаем лишь одну королеву — леди Марию. Тот, кто осмелится провозгласить право другой, поплатится за это». Его слова так напугали графа, что он не посмел осуществить задуманное и удалился, а м-р Дормер с друзьями и сторонниками отправился к королеве Марии. Он поступил так во имя права и справедливости, вопреки дружбе и родству, так как его первая жена - мать герцогини - была троюродной сестрой $^{108}$ леди Джейн. За эту услугу, а также за великую щедрость его матери к ученым католикам во времена короля Эдуарда (как уже было сказано), королева оказывала ему милости, сделав его рыцарем Бани во время своей коронации. Она также приняла его дочь, герцогиню, к себе на службу, очень любила и ценила ее, о чем еще будет рассказано в подробностях.

В годы царствования этой королевы, без малого пять лет, леди Дормер жила с сыном, продолжая творить добрые дела в отношении соседей. Но когда добродетельная католическая королева умерла, с ней умерла и забота о благочестии и религии в Англии. Унаследовав престол в 1558 г., королева Елизавета изменила управление [церковью] и принимала ереси, главными

берлена с вооруженным отрядом покинул столицу, чтобы задержать принцессу, Тайный Совет поменял сторону и 19 июля провозгласил коромевой Марию. Ажейн Грей и ее муж были отправлены в Тауэр. Оба они предстали переА судом в ноябре 1553 г., были признаны виновными в измене и приговорены к смерти. Изначально королева Мария не хотела приводить приговор в исполнение, однако в январе 1554 г. в восстании Уайатта (см. примеч. 235) приняли участие отец и Ава Аяди Ажейн, и ее

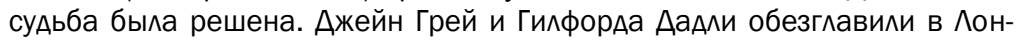
Аоне 12 февраля 1554 г.

107 Ажон Рассел (1485-1555), 1-й граф БеАфорА (с 1551 г.), морАхранитель королевской печати печати (1542-1555).

108 Ажейн Грей приходилась троюродной племянницей Мэри СиАни (1-й жены Аормера) по женской минии. 
защитниками которых были ее главные советники и командиры. Видя эти огорчительные перемены, добрая леди Дормер, немолодая летами, но исполненная рвения и любви к истинной вере, покинула дом, сына, страну и друзей, предпочтя жить в изгнании и свободно служить Господу, нежели оставаться в столь испорченном королевстве. С этой христианской целью она в 1559 г. вместе с внучкой, герцогиней Ферия, отправилась за море, во Фландрию. Незадолго до того, как герцогиня направилась из Мехельна в Испанию, леди Дормер уехала в Лувен, обустроила дом и поселилась там; в городе жили многие достойные и ученые священники-англичане, изгнанные за неподчинение новым еретическим установлениям Англии. Там она прожила остаток своих лет (около двенадцати), прославившись добродетелью, щедростью, и другими христианскими делами, так что не только город и университет, но и страна вокруг почитала ее. До сих пор знавшие ее пожилые люди вспоминают ее с похвалой. Таковы были ее щедрость и благочестие, что ученый доктор Сандерс в своей книге Visibilis monarchia ecclesiae ${ }^{109}$ восхваляет ее, как свидетель, следующими словами: «благородная вдова, леди Джейн Дормер, бабушка благороднейшей герцогини Ферия, увидев, что страна захвачена ересью, добровольно отправилась в изгнание и прожила в Лувене двенадцать лет, не просто убегая от всякой схизмы; она - опора хромого, глаза слепца, посох слабому, настоящая мать сирот и покровительница вдов». Как новая Тавифа (Доркас) ${ }^{110}$, она шила одежды для вдов и бедняков. Когда в Нидерландах был генералом герцог Альба, его армия была расквартирована по разным городам, и в Лувене был многочисленный гарнизон, солдатам которого не хватало еды и одежды. Добрая леди в своем доме утроила комнату, наполненную плащами, камзолами, штанами, чулками, шляпами и рубахами для бедных солдат, и так она одевала то сорок солдат, то еще тридцать. Когда об этом узнал герцог, он с благодарностью

109 Николас Сандер (1530-1581) - английский католический полемист и богослов-эмигрант, выпускник ОсфорАского университета. КлиффорА ссылается на его трактат "О виАимой монархии церкви" (Аувен, 1571).

110 Аеян 9: 36-40. 


\section{Генри Клиффорд. Жизнеописание леди Джейн Дормер}

признал себя обязанным ее любви и щедрости и даровал привилегии ей, ее дому и друзьям, освободив их от постоя. Он так ее ценил, что когда магистратам Лувена поступали от него требования, они всегда обращались за помощью и посредничеством к ней, называя ее своей покровительницей и заступницей.

В Чистый Четверг Святой недели она всегда собирала двенадцать вдов или бедных женщин, омывала им ноги, дарила каждой новое платье и накидку, кошелек с деньгами, и угощала их обедом в тот день и на Пасху. Ее дом был убежищем и приютом для изгнанных священников и джентльменов-католиков из ее страны; многие бедные студенты получали от нее ежедневную помощь, и ныне живущие из них в моем присутствии с благодарностью свидетельствовали об этом. Ее уважали люди всех сословий; знатнейшие дворяне, дамы и господа часто посещали ее и высоко ценили. Ее почитали университет и город Лувен, о чем свидетельствуют многочисленные оказанные ей прижизненные услуги и посмертные почести.

7 июля 1571 г. (будучи около восьмидесяти лет от роду) эта дама покинула жизнь земную ради вечной жизни с Господом. Благоговейно причастившись святых таинств церкви, она до последнего часа была в здравом рассудке и сознании, со спокойной и легкой совестью. Она завещала большое суммы бедным, коллегиям, монахам и монахиням нескольких монастырей, земли и ренты - сыну, как наследнику, а оставшееся после нее движимое имущество - полностью в распоряжение внучкигерцогини, к которой она была особенно привязана. Когда она обращалась к ней на словах, или в письме, то всегда называла ее «моя дражайшая и любимейшая дочь», что явствует из ее завещания, копией которого я располагаю. Душу она вверила Ее творцу и искупителю; она, исполненная добрых дел и других деяний христианской любви, несомненно, вознеслась к Нему немедленно, судя по ее добродетелям.

Торжественность похорон соответствовала рангу леди Дормер. Присутствовавшие на погребении многочисленные сироты, вдовы и бедняки, получили траурные одежды в соответствии с ее завещанием. В процессии по порядку следовали прелаты, доктора, регенты, ректор университета, монахи всех орденов. Дворяне и 
городские магистраты следовали, в соответствии с чином, вслед за остальными в церковь картузианской обители ${ }^{111}$, где ее погребли. На следующий день множество городских бедняков (редкий и достойный пример) собрались в ее доме, сокрушаясь о своей потере, каждый с зажженной свечей, и все по порядку прошли тем же путем, каким днем ранее несли ее тело к картузианцам, и там молились о ее душе. Этот дар удивительной любви проистекал от их собственных побуждений и благодарности.

Как я сказал, леди Дормер похоронили в церкви картузианской обители (куда при жизни ее - женщину - не допускали), в середине трансепта, прямо перед алтарем. Рядом с ней лежит также и тело внучки, леди Энн Хангерфорд, единственной сестры герцогини по отцу и по матери, которая умерла в том же городе Лувене тридцать два года спустя. Обе дамы лежат под прекрасным мраморным надгробием, окруженным мраморными колоннами; их портретные изображения в рост помешены на верху надгробия. Эпитафии и гербы, указывающие на их происхождение и брачные союзы, были сделаны за счет герцогини, из годовой ренты в сто флоринов, дарованных ею монастырю и выплачиваемых в Антверпене.

Леди Хангерфорд приехала из Англии за море в тот самый год, когда умерла ее бабушка, еще не зная о ее кончине, ибо муж, сэр Уолтер Хангерфорд был недоволен ее католическим благочестием и благородными устремлениями ${ }^{112}$. Хотя ее супруг и был благороден по происхождению, его личность и честь были запятнаны низкой жадностью и телесной распущенностью. Он не обращался с этой леди так, как подобает обращаться с женой и знатной дамой ее ранга, поэтому она получила у него разрешение уехать за море к бабушке, чтобы обрести свободу совести и свободно служить Богу. Он с радостью согласился на это, чтобы

111 Картузианское аббатство Св. Марии МагАалины у Креста в Аувене.

112 ^орА Уолтер ХангерфорА (1526-1596) в 1570 г. подал в суд, требуя разАельного проживания С женой, которую он обвинил в попытке отравить его и в аАюльтере. Леди Энн выиграла процесс, но муж отказался выплачивать ей содержание. Только после этого она покинула Англию; вполне вероятно, что католическое рвение не играло зАесь такой большой роли, какую приписывает ему КлиффорА. 


\section{Генри Клиффорд. Жизнеописание леди Джейн Дормер}

свободнее предаваться плотским удовольствиям, и чтобы избегнуть преследований из-за ее убеждений. Итак, как я сказал, она отправилась в Нидерланды и прожила там тридцать два года, пример истинного благородства и христианской жизни, почитаемая за храбрость и рассудительность; об этом хранят память в Намюре и Лувене, где она жила. Госпожа Маргарита Австрийская, герцогиня Пармская, сестра короля Филиппа II Испанского $^{113}$, правившая в те годы провинциями от имени брата, любила с ней беседовать и, зная, что она - сестра герцогини, почитала ее и выказывала ей свое расположение, часто приглашала ее к себе и хвалила другим ее благородное повеление и достоинства, равные которым встречала у немногих женщин. Губернаторы и магистраты городов, в которых жила леди Хангерфорд, при каждой опасности (ибо тогда в тех местах бушевала война) особенно заботились о ней, приходили к ней в дом, предоставляли охрану ей самой, ее семье и имуществу, показывая тем самым великую заботу о ее безопасности. Таковы были достоинства ее поведения. Во время опасности она вела себя храбро и великодушно. Она была щедра и полна сочувствия к бедствующим дворянам и бедным студентам, и раздавала много милостыни. Будучи в изгнании, она испытала горе, потеряв единственного сына во цвете юности, перед его свадьбой ${ }^{114}$; он подавал большие надежды, был благородным, рассудительным и добродетельным. То было наказание, которое Господь налагает на прелюбодеев, и я мог бы лишь желать, чтобы его отец был невиновен в этом грехе ${ }^{115}$; тогда его род продолжился бы, а теперь он рассеян.

Леди Хангерфорд оставила этот свет 19 декабря 1603 г., исполненная добрых дел, следуя стопами своей достойной бабушки.

Свидетельством достоинств и великих заслуг двух этих дам являются голоса не только простых людей, но и правителей

113 Маргарита Пармская (1522-1586), незаконнорожденная Аочь императора Карла V, жена Оттавио Фарнезе, герцога Пармского. В 1555-1567 гг. управляла Нилерландами от имени Филиппа II.

114 ЭАвард ХангерфорА умер в 1585 г.

115 Барон Хангерфорд после отьезда жены открыто жил с любовницей, МарАжери Брайт, родившей ему Авух сыновей, и Ааже пытался узаконить их отношения. 
страны, а также тех, кто служил им много лет; подтверждением служат утверждения и сочинения самых ученых людей нашей нации, тогда живших за морем, например, ученого прелата, доктора Уильяма Аллена, впоследствии - кардинала ${ }^{116}$, доктора Оуэна Льюиса ${ }^{117}$, епископа Кассанского, доктора Николаса Сандерса, доктора Томаса Степлтона ${ }^{118}$, сочинителей и преподавателей богословия, а также и пятидесяти других, подавших петицию папе Григорию XIII ${ }^{119}$ с тем, чтобы он убедил послать герцогиню в Нидерланды. Обсуждая дело с кардиналом Мороне ${ }^{120}$, их покровителем при Папском престоле и протектором английской нации, помимо прочих причин, приведенных в общем письме от 28 декабря 1572 г., указали многочисленные услуги, оказанные им герцогиней.

\section{Глава IV \\ О детстве и воспитании Джейн Дормер}

Когда Джейн Дормер, которую в раннем детстве воспитывала столь достойная госпожа, достигла разумного возраста, то первым, что она постигла, стал ее долг служить Богу и повиноваться отцу, деду и бабушке, смиренно подчиняясь их приказам. Добродетель подчинения была воспринята ею всем сердцем и, вместе с редким уважением [к старшим] не только сохранялась в ней до самой смерти бабушки, но даже возросла. Когда она служила королеве Марии в ее опочивальне, то никогда не пренебре-

116 Уимьям Алмен (1532-1594) - католический богослов и полемист, выпускник Оксфорда; преподаватель богословия в Аувенском университете (после 1562 г.), основатель Английской комеегии в Ауэ (1568). С 1587 г. - кардинал.

117 Оуэн Аьюис (1532-1594) - католический богослов и полемист, выпускник Оксфорда; преподавал каноническое право в ^увене (после 1561 г.); епископ Кассанский (1588-1594).

118 томас Степлтон (1535-1598) - католический богослов, историк и полемист, выпускник Оксфорда; после 1568 г. преподавал богословие в Английской коммегии Ауэ.

119 Григорий XIII (Уго Бонкомпаньи, 1502-1585), папа Римский в 15721585 гг.

120 Ажованни Мороне (1509-1580), итальянский богослов и Аипломат; карАинал с 1542 г. 


\section{Генри Клиффорд. Жизнеописание леди Джейн Дормер}

гала своим долгом по отношению к бабушке, всегда сообщала ей обо всех важных делах, спрашивала ее разрешения и строго выполняла то, что та ей приказывала или советовала.

Не достигнув еще семи лет, она уже читала на латыни Часослов, или, как мы говорим, Часы Богородицы, и продолжала делать это ежедневно на протяжении всех шестидесяти семи лет жизни, при любом состоянии здоровья. Она достигла удивительного искусства в вышивании, которому учат дворянских девушек. Я видел несколько образчиков ее работы, расшитые ее собственными руками, удивительные и редкие в своем совершенстве, по мнению мастериц в этом деле. Есть и различные алтарные покровы, и облачения священников и служек, богато украшенные и примечательные изобретательностью и разнообразием рисунков; все они сделаны ее руками. При этих способностях, она всегда проявляла похвальную скромность во всем, что делала и говорила.

Когда ее дед, сэр Уильям Сидни, которого король, все еще охваченный своими неумеренными страстями, избрал в наставники сыну, принцу Эдуарду, пребывал в Эшридже (что неподалеку от дома Дормеров) $)^{121}$, он послал за Джейн, чтобы она провела какое-то время в играх с принцем. Они оба были примерно одного возраста, около шести или семи лет ${ }^{122}$, и принц был старше ее всего на три месяца; он желал ее общества, получая особенное удовольствие от бесед с ней. Джейн отправили туда с гувернанткой, и она проводила время вместе с принцем, читая, играя или танцуя с ним, или занимаясь чем-либо подобным, в силу их душевных устремлений и невинности юных лет. Играя в карты, принц говорил ей: «Вот Джейн, твой король бит, так что тебе придется довольствоваться мной»

Я слышал от тех, кто служил принцу, что его склонности и природные качества побуждали его проявлять добродетель и свойства истинного государя; прекрасное дитя доброго и щедро-

121 Бывший приорат Братьев Покаяния в Бекингэмшире. После роспуска монастырей - королевский манор, резиденция детей Генриха VIII - ЭАуарда и Елизаветы. Находится в 12 км от Уинга - поместья Аормеров.

122 т.е., в 1543 или 1544 г. 
го нрава. Позднее, когда его отец умер (принцу тогда было девять лет) ${ }^{123}$, злонамеренные наставники-еретики воспользовались его юностью; злоупотребив властью во имя собственных целей, они повредили природным добрым наклонностям этого хорошего и благородного государя. Ибо, когда Эдуард стал королем, он, проезжая как-то мимо руин монастыря, спросил, что это за здания. Ему ответили: то были монастыри, распущенные и разобранные по приказу его отца, за злоупотребления. Эдуард на это сказал: «а не мог мой отец наказать виновных и оставить в неприкосновенности эти прекрасные здания, украшающие королевство, и поместить в них лучших людей, которые смогли бы населить их и управлять ими?», сожалея, кажется, об этих печальных событиях. Когда его посетила сестра, леди Мария (державшая дом в соответствии с католическими порядками), Эдуард обрадовался ее обществу (об этом я слышал от очевидца), задавал ей множество вопросов, обещая сохранить ее тайну, и обращался с ней с таким уважением и почтением, как если бы она была его матерью. Она же, проявив осмотрительность, дала ему советы относительно вещей, касавшихся его самого, и тех, что касались ее, выказав к нему большую любовь и сестринскую привязанность. Юный король заплакал, узнав, что некоторые вещи невозможно устроить согласно ее пожеланиям. Когда же его дядя-герцог ${ }^{124}$ проявил к принцессе строгость и ограничил ее свободу, Эдуард умолял ее потерпеть и подождать, пока он вырастет и все исправит. Когда она прощалась, он загрустил от расставания; поцеловав ее, он приказал принести драгоценное украшение ей в дар и пожаловался, что ему не принесли для нее ничего получше. Все это было отмечено наставниками, и пришел приказ сделать такие визиты как можно более редкими, потому что они, якобы, вводят короля в грусть и меланхолию; предполагалось также наказать ее слуг и офицеров за то, что вопреки тогдашнему закону, принцесса публично посещала мессу в своей

123 Генрих VIII умер 28 января 1547 г.

124 Брат матери ЭАуарАа VI ЭАварА Сеймур, герцог Сомерсет (1500-1552), в 1547-1549 гг. ^орА-протектор Англии, глава регентского совета при мамолетнем короле. 


\section{Генри Клиффорд. Жизнеописание леди Джейн Дормер}

часовне, если бы только удалось получить согласие у короля. Однако Эдуард ни за что на это не соглашался и строго-настрого приказал соблюдать ее свободу поступать так, как она хочет. Он послал к Марии, чтобы узнать, не побеспокоили ли ее, ибо если так случилось, то его воли на то не было, и он соглашался удовлетворить ее требования. Однако в те времена леди Марии было небезопасно и неблагоразумно жаловаться.

Когда Джейн Дормер подросла, бабушка порекомендовала ее на службу благороднейшей католической принцессе Марии. Леди Дормер подвиг к этому ее дедушка Сидни, две дочери которого служили принцессе и умерли, находясь на ее службе ${ }^{125}$; Ее Высочество высоко ценила их за добродетель. Когда королевы (жены короля Генриха) настоятельно требовали их к себе на службу, они ни за что не пожелали оставить леди Марию, хотя сам король просил об этом. В те дни дом этой принцессы был единственным приютом для благородных молодых женщин, стремившихся к благочестию и служению Богу. То была истинная школа добродетельного поведения, подобающее место воспитания благородных девиц. Знатнейшие лорды королевства просили принцессу принять их дочерей на службу.

Джейн продолжала служить леди Марии, когда после смерти короля Эдуарда ей достался престол, и оставалась с ней, пока она не покинула этот мир. В это время королева выказывала ей любовь и благосклонность, на которые Джейн отвечала должным уважением, так что королева почти никогда не позволяла ей покидать себя. Джейн спала в ее опочивальне, много раз - вместе с ней; королева читала вместе с ней Часы Богородицы; вверила ее попечению свои украшения и все драгоценности, какими обычно ведают дамы опочивальни. За столом она ела мясо, нарезанное рукой Джейн Дормер, и все это - явное доказательство ее добродетелей, ведь столь добродетельная и добронравная принцесса благоволила ей и уважала ее.

Королева редко путешествовала, выезжая только в дом кардинала в Кройдоне (ибо ее родственник, кардинал Пол, был ар- 
хиепископом Кентерберийским $)^{126}$, ни в коем случае не желая беспокоить своих подданных во время покоса и сбора урожая зерновых, когда им нужны лошади и повозки. Отдыхая в Кройдоне, она, одевшись попроще, посещала бедных соседей с двумятремя фрейлинами, и всегда одной из них была Джейн. В бедных жилищах Мария садилась поговорить с хозяином и его женой, спрашивала, чем они зарабатывают на жизнь, как идут дела, и как обращаются с ними слуги ее двора, ведь их повозки и услуги требовались для обслуживания свиты королевы. Однажды, находясь в доме угольщика, королева, сидя за столом, пока хозяин ужинал, задала ему подобный вопрос; угольщик же ответил, что в Лондоне у него забрали подводу и не заплатили. Королева спросила, потребовал ли он своих денег. Он сказал: да, у тех людей, что приказали ему работать, но не получил от них ни денег, ни удовлетворительного ответа. Она спросила: «Друг, правда ли то, что ты мне сказал?» Он ответил: «Да», и умолял ее потребовать от управляющего двором ${ }^{127}$, чтобы тот заплатил ему и другим беднякам. Королева сказала, что так и сделает и приказала ему явиться за своими деньгами на следующее утро, часов в девять десять. Как только королева вернулась ко двору, она тут же позвала к себе управляющего и так распекла его за то, что он не заплатил бедным людям, что находившиеся с ней дамы очень расстроились. Королева сказала, что у его служащих не нашлось для людей ни денег, ни добрых слов, и что он должен все исправить, ибо если она еще раз услышит о подобном, то сильно на него разгневается, что на следующее утро бедные люди должны были прийти

126 РеджинальА Пол (1500-1558), кардинал (с 1536 г.), один из папских мегатов на Тридентском соборе (1540-е гг.), в 1555-1558 гг. - папский мегат в Англии и архиепископ Кентерберийский. Потомок Йоркской ветви Плантагенетов (внук АжорАжа, герцога Кларенса, младшего брата короля Эдуарда IV). Приходился троюродным братом Генриху VIII. Манор, а позАнее - гороА Кройдон (сейчас - южный пригород ^ондона) принаАлежал архиепископам Кентерберийским. Королева Мария останавливалась в летнем Аворце архиепископа.

127 В тексте нет Ааты, поэтому не вполне ясно, о ком илет речь. При Марии I Аолжность управляющего Авора (comptroller of the household) занимал сэр Роберт Рочестер (1494-1557), а после его смерти - сэр Томас Корнуомиис (1519-1604). 


\section{Генри Клиффорд. Жизнеописание леди Джейн Дормер}

за деньгами и получить все причитающееся им, до последнего пенни. Управляющий недоумевал, как королева узнала об этом, и дамы рассказали ему, что произошло тем вечером.

Если при посещении бедных соседей королева находила их обремененными детьми, то давала им щедрую милостыню и утешала, советуя им жить нерасточительно и в страхе Божием, и заботиться о воспитании детей. Если же детей было много, она приказывала обеспечить их, отправив мальчиков и девочек в ученичество в Лондон, чтобы они могли приобрести доброе ремесло и быть в состоянии содержать себя. Так она поступила в доме бедного плотника, и в доме крестьянской вдовы. Так она проводила часы в обществе бедняков, в простоте и любезности; они же считали ее одной из фрейлин, ибо между ними не было разницы. Если же они жаловались, она поручала Джейн Дормер запомнить все подробности их жалобы.

\section{Глава V \\ Брак Джейн Дормер и герцога Ферии. Очерк жизни и характера королевы Марии}

Особая благосклонность, какую королева выказывала Джейн Дормер, а также редкие качества ее ума и нрава стали теми причинами, благодаря которым знатнейшие дворяне искали ее руки в браке; например, Эдвард Кортни, граф Девоншир, сын маркиза Эксетера и троюродный брат королевы ${ }^{128}$. Его королева Мария выпустила из Тауэра во время своего торжественного въезда туда ${ }^{129}$, одновременно с другими заключенными, а среди них были герцог Норфолк ${ }^{130}$, епископы Боннер ${ }^{131}$, Тансталл ${ }^{132}$ и

128 ЭАварА Кортни (1527-1556), граф Аевон, сын Генри Кортни, 1-го маркиза Эксетера, и Гертруды Блаунт, троюродный брат Марии I (их бабушки, королева Елизавета Йоркская и Кэтрин, жена Уильяма Кортни, графа Аевона, были родными сестрами). Его отец был обвинен в соучастии в заговоре против Генриха VIII и казнен в 1539 г.; ЭАварА был арестован вместе с родителями и провел в заключении в Тауэре 15 лет (15381553). Мария I освободила его из-под ареста и вернула земли и наслеАственный титул.

1293 августа 1553 г.

130 Томас Ховард, 3-й герцог Норфолк (1473-1554) был арестован в 1546 г. вместе с сыном, Генри Ховардом, графом Сарри, обвиненным в 
Гарднер $^{133}$. Последний был сторонником этого союза, зная о привязанности графа к девушке; некоторые же считали, что он всего лишь хотел предотвратить брак графа и леди Елизаветы ${ }^{134}$, от чего впоследствии и проистекли все ее злоключения в царствование королевы Марии. Он говорил с королевой о браке Джейн и уговаривал саму девушку, чтобы добиться заключения союза. Другими ее поклонниками были герцог Норфолк, в то время - единственный герцог в Англии ${ }^{135}$, и другие знатные дворяне, что признал позднее в своем завещании герцог Ферия,

измене (за то, что использовал в своем личном гербе королевскую символику - т.н. "герб Эдуарда Исповедника"). Оба были объявлены вне закона и приговорены к казни, но герцога спасла смерть Генриха VIII в январе 1547 г. Приговор не привели в исполнение, но герцог оставался в Тауэре Ао тех пор, пока его не освободила королева Мария. Ему вернули земли, титулы и наследственную Аолжность графа-маршала, а также ввели в состав Тайного Совета.

131 ЭАварА Боннер (1500-1569), епископ Мондонский в 1539-1549 и 1553-1559 гг.; в Тауэр он попал за отказ принять протестантскую литургию. При Елизавете он по той же причине был смещен с посла, вновь отправлен в тюрьму (Маршалси), гАе и умер.

132 Катберт Танстам^ (1474-1559), епископ АонАонский в 1522-1530 гг., Аарэмский в 1530-1551 и 1553-1559 гг. Был взят поА стражу в 1551 г. и помещен сначала под Аомашний арест, а затем в Тауэр. В 1559 г. был мишен кафеАры и отправлен поА арест в лондонскую резиденцию архиепископа Кентерберийского (Лэмбет), гАе и умер.

133 Стивен Гаранер (1483-1555), епископ Винчестерский в 1531-1551 и 1553-1555 гг., за отказ признать протестантское учение о евхаристии попа^ в Тауэр; после освобожАения в 1553 г. Мария I назначияа его на пост лорда-канциера.

134 Поскольку граф Аевон был англичанином и приходился правнуком ЭАуaрAу IV, он облаАал правами на английский престол, поэтому часть советников выступали сторонниками брака его и королевы. КогАа Мария выбрала испанский брак, недовольные Аворяне (по большей части протестанты) подняли восстание. Кортни подАерживал контакты С восставшими, которые планировали посадить на престол вместо Марии его и Елизавету. После подавления восстания летом 1554 г. Кортни был вновь арестован. Весной 1555 г. он был отправлен в изгнание и поселился на территории Венецианской республики. Умер он в Падуе 18 сентября 1556 г.

135 Имеется в виду Томас ХоварА, 4-й герцог Норфолк (1536-1572), унаследовавший титул после смерти АеАа в 1554 г. 


\section{Генри Клиффорд. Жизнеописание леди Джейн Дормер}

ходатайствуя за Джейн перед королем, отметив: в своей стране она отвергла более знатных искателей ее руки. Нынешний лордадмирал, граф Ноттингэм ${ }^{136}$, ее ровесник, в то время провозглашавший ее своей госпожой, сказал мне, будучи послом в Испании в 1605 г. ${ }^{137}$, что она была прекраснейшей и нежнейшей женщиной на свете; что ею восхищался весь двор, и все почитали ее за ее собственные достоинства и за то уважение, которое ей оказывала королева. Однако в брачных делах Джейн не могла ничего сделать без согласия королевы, не желавшей с ней расставаться; говоря об этом, королева обычно замечала, что Джейн Дормер заслуживала самого лучшего мужа, и добавляла также, что не знает достойного ее мужчину. Если Джейн случалось разболеться так сильно, что она не могла прислуживать королеве, Ее Величество проявляла к ней удивительные заботу и внимание, что больше подобает матери или сестре, но не королеве и госпоже. В последние дни жизни этой благословенной королевы, когда она направлялась из Хэмптон Корта ${ }^{138}$ в Лондон, а Джейн почувствовала недомогание, Ее Величество не позволила ей отправиться баржей по воде, по отправила ее посуху в собственном паланкине, в сопровождении своего собственного врача. Приехав в Лондон, она первым делом спросила о Джейн Дормер, которая, встретив ее у подножия лестницы, сказала, что чувствует себя лучше. Королева ответила: «а я - вовсе нет», и было это в конце августа 1558 г. Она отправилась в свои покои и больше никогда их не покидала.

В это время король находился во Фландрии и был занят военными действиями, которые шли тогда на границе с Франци-

136 Чарльз Ховард, барон Эффингэм (1536-1624), с 1596 г. - граф Ноттингэм. ^орА-аАмирал в 1585-1619 гг.

137 Граф Нотингэм участвовал в мирных переговорах между Англией и Испанией в 1604 г. и возглавил английское посольство в Испанию весной 1605 г. В Испании он контактировал с английскими эмигрантами и даже был принят в Английской колмегии ВальяАолиАа, готовившей католических священников Аля Англии.

138 Хэмптон Корт - королевская резиденция близ Ричмонда; построена в 1515-1529 гг. кардиналом Уолси и позднее расширена Генрихом VIII. 
ей ${ }^{139}$. Он узнал о болезни королевы, находясь в расположении армии близ Дурлана ${ }^{140}$, и послал герцога Ферию, чтобы тот служил королеве и помогал ей во всем, что потребуется. Господу Всемогущему было угодно сделать так, что болезнь оказалась смертельной; усиливаясь день ото дня, она, в конце концов, унесла ее в лучший мир. Джейн постоянно находилась вместе с королевой, не будучи еще замужем, так как королева не позволяла ей обвенчаться до возвращения короля из Фландрии. По этой причине не было сделано богатых даров и пожалований, которыми королева собиралась, как обещала, отметить ее свадьбу, и Мария I сожалела об этом. Поняв, что она умирает, королева сказала Джейн: она была бы счастлива видеть ее свадьбу, однако Господь решил иначе - больная и в отсутствии короля она не в состоянии сделать желаемое. Ее болезнь повергла в траур все королевство, однако сама королева переносила страдания с христианским терпением. Она утешала тех, кто сокрушался о ней; рассказывала им, какие прекрасные сны видела: дети, подобные ангелочкам, играли перед ней, пели ласкающие слух песни, давая ей больше, чем земное утешение, и таким образов побуждала всех иметь страх Божий, освобождающий от зла и умеряющий все искушения. Она просила их помнить о том, что все, что ни случается с ними, происходит по Божьему произволению, и всегда верить, что Он в милости своей все устроит к лучшему.

С самого начала злоключений ее матери королеве пришлось многое перетерпеть, а радостных дней было немного - лишь тогда, когда она восстановила в своих королевствах католическую религию. В короткие годы своего правления королева столкнулась с многочисленными заговорами, и все они проистекали от злобных наветов на истину Господню. Королева Мария приказала всем своим советникам и слугам оставаться верными католической религии и с этим добродетельным христианским советом, помолившись и выслушав наставления, причастившись

139 На последней стадии Итальянских войн, в 1556-1558 гг. военные действия межАу Францией и Габсбургами сосредоточились на пограничных территориях Фланарии и Северной Франции.

140 Аурлер в провинции Эно. 
святых таинств церкви, покинула этот мир 17 ноября 1558 г. Тем утром, она слушала мессу, которую отслужили в ее опочивальне, хотя она уже была близка к концу (ибо она слушала мессу каждый день своей жизни), и, едва живая, слушала с вниманием, рвением и благочестием, отвечая вместе со служкой; таковы были живость ее органов чувств и память. Когда же священник дошел до слов Agnus Dei, qui tollis peccata mundi, она ответила прямо и четко, чтобы все слушали: Miserere nobis, Miserere nobis, Dona nobis pacem ${ }^{141}$. После этого она молилась про себя, а когда священник причащался, принимая освященную гостию, она славила ее голосом и жестом, а затем закрыла глаза и вверила свою блаженную душу Богу. Так рассказывала мне герцогиня, и слезы лились из ее глаз: последним, что королева видела в этой жизни, был ее Спаситель и Искупитель в таинстве, несомненно, немедленно после того она лицезрела Его во славе на небесах.

Добрая королева Мария вверила Джейн Дормер некие предметы, которые надлежало вручить ее сестре, леди Елизавете, а также повелела передать свои слова той, что должна была наследовать королевство; все это Джейн исполнила точно, передав Елизавете драгоценности, находившиеся в ее ведении, причем королева Елизавета приняла их с радостью, и изложила вверенное ей послание. Оно заключалось в следующем: сохранить католическую веру, проявить щедрость к ее [Марии] слугам и заплатить то, что им причиталось по праву. Относительно того, что касается религии: я не знаю, по каким низким причинам или другим дьявольским соображениям политики она [Елизавета] изменила мнение, однако во время болезни королевы она обещала сохранить католическую веру. На протяжении всего царствования королевы Марии леди Елизавета ежедневно слушала две мессы - за живых и за умерших, и казалось, особенно почитала Деву Марию. Когда же во время ареста ее спрашивали о вере, она молила Бога разверзнуть землю под ее ногами и поглотить ее заживо, если она не была доброй католичкой. Все это подтвер-

141 Agnus Dei - митания, звучащая во время мессы: Agnus Dei, qui tollis peccata mundi, miserere nobis. / Agnus Dei, qui tollis peccata mundi, miserere nobis. / Agnus Dei, qui tollis peccata mundi, dona nobis pacem. 
ждается письмом королю от герцога Ферии, который во время болезни королевы посещал леди Елизавету, заверившую его в том, что исповедует католическую религию, верит в реальное присутствие Тела и Крови Христовой в гостии, и не склонна ничего менять в основных положениях официального вероучения.

Ниже я расскажу о рождении этих двух королев, а затем о других событиях их жизни, только правду, и по большей части - из свидетельств протестантских сочинителей.

Королева Екатерина была на пять лет старше мужа и сильно отличалась от него привычками. Она вставала в полночь на монашескую утреню. В пять утра она вставала и как можно быстрее собиралась, говоря, что время, потраченное на украшение себя, потеряно зря. Под королевским облачением она носила францисканскую рясу, принеся обет терциария. Она постилась, вкушая хлеб и воду, по пятницам и субботам, а также в кануны богородичных праздников. По воскресеньям она причащалась святых таинств, ежедневно читала Часы Богородицы, проводила большую часть утра в церкви на службе, а после обеда читала стоявшим рядом с ней фрейлинам житие святого, чью память отмечали в тот день. Затем она опять возвращалась в церковь. Она мало ела на ужин. Во время коленопреклоненных молитв она вставала на голый пол, а не на подушку. Она была любезна в разговоре, вежлива со всеми, доброго и благочестивого нрава. Эта дама, зерцало доброты, столкнулась со множеством бедствий, чтобы в испытаниях сладость ее добродетели распространилась на весь христианский мир.

Генрих VIII, уставший (как кажется), от своей доброй королевы Екатерины после пятнадцати лет совместной жизни, по наущению кардинала Уолси ${ }^{142}$ начал заявлять о сомнениях относительно законности своего с ней брака, ибо до того она была

142 Томас Уолси (1473-1530), архиепископ Йоркский (1514-1529), кардинал (1515-1530), папский мегат в Англии (1518-1530), ^орА-канциер (1514-1529); первый министр короля Генриха VIII, попавший в опалу изза невозможности добиться аннулирования королевского брака в Риме. Уолси не был инициатором Аела о разводе - им был сам король, - но он активно подАерживал план развода и нового брака короля, который мог бы обеспечить стране наследница мужского пола. 
женой его брата ${ }^{143}$. Папа Юлиан II дал законную диспенсацию, объявлявшую брак истинным ${ }^{144}$. Когда рассматривалось дело о разводе, богослов, славный мученик, доктор Джон Фишер ${ }^{145}$, светоч не только королевства Англии, но и всего христианского мира, подал легатам свой ученый трактат в защиту брака, советуя им не рубить сгоряча и не позволять искажать явную всем истину Священного Писания и церковных законов, доказанную в данном случае; подумать также и о том, какие великие бедствия последуют за этим разводом - вражда между королем Генрихом и императором Карлом ${ }^{146}$, и государями - их союзниками. Самое же страшное - раздоры в вопросах веры, схизма, ересь и бесчисленные секты. «Я (говорил он) много работал над этим делом, проявив наибольшее усердие, на какое способен, и дерзаю подтвердить то, о чем написал в своем сочинении, и что ясно доказывается свидетельством Священного Писания и Святых Отцов, готовностью пролить кровь, заявляя: на земле нет власти расторгнуть этот брак, соединенный самим Господом».

Это, наряду с сочинениями других ученых и благочестивых защитников, представленных легатам, убедило последних, хотя среди них был и сам кардинал Уолси ${ }^{147}$, не выносить вердикта,

143 Артур, принц Уэльский (1486-1502), старший сын и наследник короля Генриха VII Английского. 14 ноября 1501 г. женился на Екатерине Арагонской.

144 Екатерина впоследствии утверждала, что из-за юности обоих интимных отношений между ею и ее первым мужем, принцем Артуром, не было (т.е., брак не считался состоявшимся), что делало возможным зак^ючение второго брака с братом покойного супруга на основании особого разрешения (Аиспенсации) папы Юлия II, выланного в декабре 1503 г.

145 Ажон Фишер (1469-1535), ученый, богослов, епископ Рочестерский в 1504-1535 гг., кардинал (1535). Казнен за отказ признать короля главой церкви Англии. Канонизирован католической церковью как мученик в 1935 г. Выше идет речь о выступлении Фишера в защиту законности брака Генриха и Екатерины в мегатском суде 1527 г.

146 Карл V Габсбург (1500-1559), король Испании (1516-1556) и Неаполя (1516-1554), император Священной Римской империи (1519-1556).

147 ^егаты, рассматривавшие в 1527 г. в ^ондоне прошение Генриха VIII об аннулировании его брата - Томас Уолси в качестве папского мегата в Англии и специально присланный с этой целью кардинал ^оренцо КампеАжио (1474-1539). Суд в Англии закончился неудачей Аля Генриха VIII, т.к. в от- 
которого желал король. Не соглашался на это и тогдашний папа Климент VII ${ }^{148}$, хотя ему, пребывавшему тогда в состоянии войны с императором Карлом ${ }^{149}$, король Генрих обещал содержать четыре тысячи солдат в сражениях против императора. Настолько сильно желал он развода, чтобы жениться на Анне Болейн ${ }^{150}$. Он посылал дары и взятки во все университеты, чтобы там высказали благоприятное для него мнение о разводе. В письме к императору кардинал Уолси намекнул, что король может затем жениться на госпоже Маргарите, прекрасной даме, вдове герцога Алансонского и сестре французского короля Франциска ${ }^{151}$. Томас Кранмер ${ }^{152}$, капеллан сэра Томаса Болейна ${ }^{153}$, предполагаемого отца Анны Болейн ${ }^{154}$, был таким, каких король лю-

вет на прошение королевы Екатерины папа Климент постановия рассматривать дело в его собственной курии и отозвал полномочия легатов.

148 Климент VII (Ажулиано де Медичи, 1478-1534), папа Римский в 15231534 гг.

149 Папа Климент VII в союзе с королем Франции, герцогом Миланским, Генуэской, Фморентийской и Венецианской республиками выступия против Габсбургов, стремясь изгнать их войска из Италии. Военные действия были неудачными Аля союзников, а в мае 1527 г. армия императора захватила и разграбила Рим, что фактически вывело папу из числа участников конфликта. В 1529 г. папа заключил мир с императором и короновал его в 1530 г. в Болонье.

150 Анна Болейн (1507-1536), Аочь сэра Томаса Болейна и Элизабет ХоварА, фрейлина королевы Екатерины с 1522 г. Ее роман с Генрихом VIII начался ок. 1525 г. В 1532 г. первый брак короля был аннулирован, а 14 декабря 1532 г. он женился на Анне.

151 Маргарита (1492-1549), Аочь Шарля, графа Ангулемского и луизы Савойской, старшая сестра французского короля Франциска І. В 1509 г. она стала женой герцога Шарля Ангулемского (1489-1525). В 1526 г. Маргарита вышла замуж за Генриха II (1503-1555), короля Наваррского в 1517-1555 гг.

152 Томас Кранмер (1489-1556), английский богослов-протестант, архиепископ Кентерберийский в 1533-1555 гг. В конце 1520-х гг. - начале 1530-х гг. он пользовался покровительством семьи Болейн, которому и был обязан своим высоким назначением.

153 Томас Болейн (1477-1539), граф Уилтшир и ОрмонА; тюдоровский Аипломат и приАворный, в 1521-1525 гг. - казначей Авора, в 15301536 гг. - ^орА-хранитель королевской печати. 
бил: он делал то, что было угодно королю, льстил ему и выполнял все его требования. Он вынес вердикт, согласно которому королеву Екатерину впредь нужно было именовать вдовствующей принцессой Уэльской, вдовой принца Артура, а Анну полагалось считать законной королевой ${ }^{155}$.

Мистер Кемден ${ }^{156}$ скрывает дату свадьбы Анны Болейн ${ }^{157}$, так как леди Елизавета родилась всего четыре месяца спустя. Удивительно, но он не указывает и дату обручения короля с ней, а также и день свадьбы и коронации ${ }^{158}$, ведь она была матерью той, о чьей жизни и правлении он писал ${ }^{159}$. Он говорит только, что Елизавета родилась 7 сентября 1533 г. в Гринвиче. Королеву Екатерину прогнали от королевского двора в Кимболтон ${ }^{160}$, где она и жила с фрейлинами до 6 января 1536 г., дня, когда она

154 ЗАесь автор ссылается на слухи, ходившие о семье Болейн, а точнее, о матери королевы. Леди Элизабет Болейн (1480-1538), Аочь Томаса Ховарда, 2-го герцога Норфолка от его первого брака с Элизабет Тияни, провела при Аворе почти всю взрослую жизнь в качестве Аамы свиты королевы Елизаветы Йоркской, а затем - Екатерины Арагонской. Рассказывали, что она была любовницей короля Генриха VIII, которого Ааже называли отцом ее дочери Анны. ОАнако никаких подтвержАений этим слухам нет; вероятнее всего, Элизабет Болейн спутали с Элизабет Блаунт - матерью незаконнорожденного сына короля.

155 Первый акт о престолонаследии 1534 г. (25 Hen VIII с 22).

156 Автор зАесь и ниже полемизирует с английским антикварием Уильямом Кемденом (1551-1623), а точнее, с его трудом, посвященным царствованию королевы Елизаветы: Annales rerum Anglicarum et Hibernicarum regnante Elizabetha, ad annum salutis $(1615,1625)$

157 Генрих VIII И Анна Болейн были тайно обвенчаны 14 ноября 1532 г. (их Аочь Елизавета была зачата после этой Ааты). ОАнако брак с Екатериной Арагонской (который король уже счел незаконным) был провозглашен неАействительным только 23 мая 1533 г., так что пара была объявлена мужем и женой мишь 28 мая 1533 г., когАа беременность Анны уже Аолжна была быть заметной. Именно эту Аату имеет в виду КлиффорА.

158 Анна Болейн была коронована 1 июня 1533 г. в в Вестминстере.

159 Т.е., королевы Елизаветы.

160 Манор и замок Кимболтон посреди болот восточного КембриАжшира в начале XVI в. принадлежал семье УингфилА. В 1533 г. туда была отправ^ена Екатерина Арагонская (за отказ признать себя вдовствующей принцессой Уэльской, а не королевой). Считается, что промозглый климат Кимболтона способствовал ее ранней смерти. 
оставила земную жизнь. Говорят, что ее дни сократила нездоровый воздух, но главным образом - непрекращавшийся поток бедствий и страданий. Некоторые же даже подозревали отравление, потому что леди Анна безмерно ненавидела ее. Когда король узнал о ее смерти, он прослезился и приказал свите облечься в траур; однако его новая жена нарядилась в желтое, радуясь еe тихой смерти. Тело королевы Екатерины похоронили в Питерборо $^{161}$. После изгнания от двора ее не могли убедить удалиться в монастырь, хотя она и желала монашеской жизни; однако она не хотела делать ничего, что могло бы повредить ее браку, пусть это и подвергало ее бедствиям и опасностям. Отказывалась она и уехать в Испанию или Фландрию, куда ее приглашал племянник-император, хотя там бы ее приняли с почетом. Она же считала, что выпавшие ей на долю горести случились в искупление казни принца Эдварда Плантагенета ${ }^{162}$, сына герцога Кларенса ${ }^{163}$, брата короля Эдуарда $\mathrm{IV}^{164}$. Его (невинного) Генрих VII ${ }^{165}$ приказал казнить, чтобы государство стало безопасным для его потомков, а также ради того, чтобы побудить короля Фердинанда ${ }^{166}$ отдать свою дочь Екатерину в жены принцу Артуру ${ }^{167}$. Перед смертью она написала два исполненных бла-

161 Екатерина Арагонская была похоронена в церкви бенедиктинского аббатства Св. Петра в Питерборо, которая после роспуска монастырей стама кафедральным собором новообразованной епархии Питерборо.

162 ЭАварА, 17-й граф Уорик (1475-1499), сын АжорАжа Плантагенета, герцога Кларенса, и Изабеммы Невилм, графини Уорик.

163 АжорАж Плантагенет, герцог Кларенс (1449-1478), третий сын Ричарда Плантагенета, герцога Йорка и Сесили Невимл.

164 ЭАуарА IV (1442-1483), старший сын Ричарда Плантагенета, герцога Йорка и Сесили Невимл, король Англии в 1461-1470 и 1471-1483 гг.

165 Генрих VII Tюдор (1457-1509) - король Англии в 1485-1509 гг.

166 Отец Екатерины Арагонской ФерАинана II (1452-1516), король Арагона в 1479-1516, Сицилии - в 1468-1516, Неаполя - в 1504-1516, Наварры - в 1512-1516 гг.

167 Хотя король РичарА III объявил ЭАварда Плантагенета, графа Уорика, мишенным права наследования короны после объявления его отца, герцога Кларенса, вне закона в 1478 г., многие все равно считали юношу наслеАником Йорков по мужской минии. Генрих VII с 1485 г. Аержал графа Уорика под арестом в Тауэре. В 1499 г. он был обвинен (по всей виАимости, ложно) в причастности к заговору, ставившему своей целью 
гочестия письма, одно - королю, другое - духовнику, брату Фостеру, который тогда был в тюрьме, а затем, после жестоких пыток прославился как мученик ${ }^{168}$. Таков был конец этой великой королевы и святой государыни, известной всем народам и прославленной большинством авторов того времени.

Пятью месяцами позже королева Анна была призвана на суд в мир иной, но после жизни, во всем отличной от предшественницы. Эта жизнь прошла в развлечениях, танцах, играх и прочих телесных усладах, в которых она отличалась особым изяществом - искушением и призывом к плотским удовольствиям, позорящим и губящим тех, кто ранее славился добродетелью. С того времени, как на защиту королевы Екатерины выступил ученый и неколебимый защитник, епископ Рочестерский ${ }^{169}$, Анна всеми силами старалась погубить его. Некоего Ричарда Райса, повара, подговорили отравить епископа, и он не додумался ни до чего лучшего, кроме как отравить весь колет с пищей, предназначавшейся для свиты епископа. Случилось так, что в тот день епископ не пришел по своему обыкновению обедать в общем зале, но большая часть поевших там домочадцев отравились и умерли. Повара Райса поймали, он во всем признался и был казнен ${ }^{170}$. Когда же дворянин сообщил королю, что сэра Томаса Мора

способствовать бегству из тюрьмы другого заключенного - Перкина Уорбека (выдававшегося себя за Ричарда Йоркского, младшего сына Эдуарда IV, т.е., одного из "принцев из Тауэра"). Екатерина Арагонская считала себя виноватой в смерти невинного принца, так как ее родители, Фердинанд II и Изабемла Кастильская, отказывались выдавать ее замуж за английского принца до тех пор, пока не окажется подтвержденным право на престол его отца (а фактически, пока Генрих VII не устранит всех потенциальных конкурентов из минии Йорков).

168 Имеется в виду Ажон Форрест (1477-1538), богослов-францисканец, глава английской провинции францисканцев-обсервантов, Ауховник Екатерины Арагонской. 22 мая 1538 г. он был сожжен на костре за ересь (отказ признать короля главой церкви вместо папы).

169 Ажон Фишер (см. примеч. 145).

170 Ричард Рус был арестован, подвергнут пытке и признался в том, что подложил в еАу слабительное "раАи шутки". Ему не поверили и приговорили к смерти актом объявления вне закона. 5 апреля 1531 г. его заживо сварили в котле в СмитфилАе (близ Лондона). 
обезглавили ${ }^{171}$, король сидел за игорным столом, а леди Анна стояла рядом. Король отшвырнул кости, выказав гнев и горе, и сказал ей: «Все это из-за тебя; честнейший человек моего королевства мертв», и внезапно ушел в расстройстве.

Вернемся к ее смерти. Королю, похоже, приглянулась Джейн Сеймур, и однажды королева Анна увидела, как король посадил ее себе на колено. Считали, что королева тогда была беременна и изза ярости и гнева выкинула ${ }^{172}$, как она сказала королю, который, опечалившись, просил простить его и обещал больше не вызывать ее неудовольствия таким образом. Королева же, желая родить сына - наследника престола, и видя, что король не удовлетворяет ее, ради этой цели связалась ${ }^{173}$ с собственным братом, лордом Джорджем Болейном, виконтом Рочфордом ${ }^{174}$, джентльменами опочивальни — Фрэнсисом Уэстоном ${ }^{175}$, Генри Норрисом ${ }^{176}$, Уильямом Бреретоном $^{177}$, и музыкантом Марком Смитоном ${ }^{178}$, за что

171 Сэр Томас Мор (1478-1535) - английский гуманист; спикер Палаты Общин в 1523 г., канцлер герцогства ^анкастерского в 1525-1529 гг., морА-канцлер в 1529-1532 гг. В 1534 г. арестован за отказ принести присягу королю как главе церкви; был признан виновным в измене и казнен (обезглавлен) 6 июля 1535 г. Английские католики почитали его как святого мученика уже в XVI в.; канонизирован он был в 1935 г.

172 В конце января 1536 г. Анна Болейн перенесла выкидыш (примерно трехмесячного плода мужского пола). Причиной выкидыша называли стресс, перенесенный ею, когАа Генрих VIII был сбит с коня во время турнира и Ава часа не приходил в себя; Аругой причиной стресса называли и описанный выше эпизоА с Ажейн Сеймур.

173 Официальной причиной обвинения королевы Анны в измене и инцесте были объявлены ее мюбовные связи с вышеперечисленными придворными, в том числе и ее собственным братом.

174 АЖорАЖ Болейн, виконт РочфорА (1503-1536), Аворянин королевской опочивальни, в 1534-1536 гг. смотритель Пяти портов и констебль Ауврского замка.

175 Сэр Фрэнсис Уэстон (1511-1536), Аворянин королевской опочивальни, близкий Аруг Генриха VIII.

176 Сэр Генри Норрис (1482-1536), Аворянин королевской опочивальни, близкий Аруг Генриха VIII.

177 Сэр Уильям Бреретон (1487-1536), Аворянин королевской опочивальни.

178 Марк Смитон (1512?-1536), приАворный певец и музыкант, возможно, фламандец. 


\section{Генри Клиффорд. Жизнеописание леди Джейн Дормер}

их всех предали смерти ${ }^{179}$. Через три дня, 14 мая 1536 г. $^{180}$, саму Анну Болейн обезглавили. Председателем суда был герцог Норфолк ${ }^{181}$. Ее осудили и приговорили двадцать шесть пэров, в том числе и ее отец, вскоре после того умерший от горя. Ей не было и двадцати девяти лет. Мы видим, какими разными были матери двух королев, и отцовство второй сомнительно; королева Мария никогда не называла Елизавету сестрой и не верила, что та - дочь ее отца. Она говорила, что у Елизаветы - лицо и фигура Марка Смитона, который был очень красивым мужчиной. Однако мы перейдем к их образованию.

В коротком рассказе о воспитании и эпизодах из жизни королевы Марии I я скажу, что она была воспитана добродетельной матерью, в княжеской роскоши и в истинном благочестии, научена знать Господа и служить Ему, и всегда пребывать в страхе Божием. Впоследствии ее дальнейшее образование было вверено графине Солсбери ${ }^{182}$, матери кардинала Пола и двоюродной сестре королевы - ее бабушки, благочестивой женщины, уподоблявшейся святым $^{183}$. Мария была провозглашена принцессой Уэльской и наследницей королевства ${ }^{184}$; научена ненавидеть зло, не знала грубых и нечистых речей. Когда об этом узнал отец, то не поверил и одна-

179 Предполагаемые любовники Анны Болейн были казнены 17 мая 1536 г.

180 Ошибка автора: казнь Анны состоялась 19 мая 1536 г. 14 мая ее брак с королем был объявлен аннулированным.

181 Аяая Анны, Томас ХоварА, герцог Норфолк (см. примеч. 130).

182 Маргарет Пол (урожА. Плантагенет), графиня Солсбери (1473-1541), Аочь Ажоража Плантагенета, герцога Кларенса, и Изабелмы Невимл, старшая сестра графа Уорика (см. примеч. 133 и 134); жена сэра Ричарда Пола (1462-1505). Придворная Аама и воспитательница принцессы Марии в 1520-1533 гг. В 1539 г. ее и ее сыновей обвинили в измене - переписке с младшим сыном, РеАжинальАом Полом, который в 1536 г. покинул Англию, отказавшись признать короля главой церкви. Старший сын графини, Генри Пол, барон Монтегю, был казнен в 1539 г., а его мать Ава года провела под арестом и была казнена 27 мая 1541 г.

183 Имеется в виду мать Генриха VIII Елизавета Йоркская.

184 Марию никогАа формально не объявляли принцессой Уэльской, оАнако в 1525 г. она была отправлена в АаАлоу во главе собственного Авора, как глава Совета Вамлийской марки и облаАательница других прерогатив принца Уэльского. 
жды, во время бала, велел сэру Фрэнсису Брайану испытать ее. Узнав же, что это - правда, и сочтя ее рассудительной особой с королевским разумением, еще больше стал почитать ее. Однажды в Элтеме ${ }^{185}$ она и Анна Болейн слушали мессу, находясь в одной комнате. В конце службы леди Мария, низко присев перед ней, оправилась в свои покои, так же поступила и леди Анна, которую тогда называли королевой. Когда леди Анна пришла к себе, одна из фрейлин сказал ей, что при расставании леди Мария присела перед ней в реверансе; она ответила, что не заметила этого, сказав: «если бы мы это заметили, то поступили бы так же по отношению к ней», а затем немедленно послала к ней даму своей свиты с извинениями, добавив, что ничья любовь не ценится ею выше, чем ее, и она примет ее с нежностью истинного друга. Дама пришла с посланием, когда леди Мария обедала. Войдя, она сказала: «королева с любовью приветствует вашу милость и просит прощения, ибо, когда вы обе вышли из молельни, вы присели перед ней в реверансе, и если бы она это заметила, то ответила бы тем же. Она хотела бы видеть в этом начало дружеского общения, и ваша милость найдет ее совершенно к вам расположенной». «Невозможно», отвечала леди Мария, «чтобы королева велела передать мне эти слова, и неподобающе; и не могло это произойти так быстро, ведь она находится далеко от этого места. Вы должны были бы сказать — леди Анна Болейн, ибо я не могу признать никакой другой королевы, кроме моей матери, и не могу считать друзьями тех, кто не являются и ее друзьями. Что же до реверанса, он был обращен к алтарю Творца нашего; те же, кто говорят иначе, обмануты и обманывают ее». Леди Анна пришла в ярость от такого ответа, заявив, что в один прекрасный день сломает это упорство.

Луис Вивес ${ }^{186}$ в 1524 г. посвятил ей двести тридцать Symbo$l a^{187}$, или кратких сентенций, которые мы обычно называем деви-

185 Аворец в Элтеме (близ Гринвича) был королевской резиденцией в XIVXVI вв.

186 Хуан Ауис Вивес (1493-1540), испанский гуманист. Его трактат De institutione feminae christianae (1523) был заказан королевой Екатериной Арагонской как наставление Аля ее Аочери Марии.

187 Имеется в виду главный педагогический труд Вивеса: Introductio ad sapientiam ... eiusdem satellitium animi, sive symbola (1524). 
зами, с парафразами на каждый из них. Первый из них гласил: Scopus vitae Christus ${ }^{188}$, а последний - Mente Deo defixus ${ }^{189}$. Она всегда помнила их, и сделала образом жизни. Она сделала началом и концом всех ее действий Христа, от благодати которого проистекают все вещи, к Кому они стремятся, и живым примером тому была ее собственная мать.

Все соседние короли и князья стремились получить ее руку. Яков V, король шотландцев ${ }^{190}$, затем император Карл ${ }^{191}$, немедленно предложивший ей во владение Нидерланды; потом французский король ${ }^{192}$ от имени своих сыновей, сначала - дофина ${ }^{193}$, а потом - герцога Орлеанского ${ }^{194}$. Когда же король Генрих отверг обоих по причине их юного возраста, король Франциск предложил самого себя ей в мужья. Такова была слава ее добродетели и достоинств. По разным государственным соображениям ни один из женихов не преуспел.

В царствование короля Эдуарда, когда новые правители изменили религию, принцессу Марию нельзя было ни угрозами, ни уговорами лорда-протектора ${ }^{195}$ и других заставить закрыть молельню, или же не допускать никого постороннего в домашнюю

188 Христос - цель жизни (лат.)

189 Ум, обращенный к Богу (лат.).

190 Яков V Стюарт (1512-1542), король Шотланаии в 1513-1542 гг., сын Якова IV и Маргарет ТюАор, сестры Генриха VIII.

191 Принцесса Мария была обручена со своим кузеном Карлом V в 1521 г., когАа ей было всего пять лет. В 1525 г. помолвка была расторгнута, и император женился на Изабемле Португальской.

192 Франциск I Валуа (1494-1547), король Франции в 1515-1547 гг.

193 Франсуа (1518-1536), Аофин, герцог Бретонский, старший сын короля Франциска I и К^оА, герцогини Бретонской. Аофин был обручен с принцессой Марией в 1518 г. Помолвку расторгли в 1521 г., после чего Марию обручили с императором Карлом V (см. примеч. 146).

194 Генрих II (1519-1559), младший сын старший сын короля Франциска I и К^оА, герцогини Бретонской, герцог Орлеанский в 1519-1536 гг., Аофин в 1536-1547 гг.; король Франции в 1547-1559 гг. В 1527 г. межАу Англией и Францией был подписан Аоговор, преАполагавший, помимо прочего, брачный союз межАу Марией и Генрихом (либо его отцом Франциском I).

195 ЭАварА Сеймур, герцог Сомерсет (см. примеч. 124). 
часовню, где открыто служили мессу каждый день, или принять хоть малейшее отступление от католической религии. Когда же она увидела, каким путем идут новые правители, нарушившие последнюю волю ее отца, соблюдать которую они поклялись перед его смертью, она храбро и откровенно написала лордупротектору, призывая его и остальных членов Совета задуматься о том, что они делают и не злоупотреблять несовершеннолетием короля, изменяя законы, волю и постановления их отца, короля Генриха, ибо их могут призвать к ответу за содеянное, когда ее брат-король достигнет совершеннолетия. Она также сказала им, что они не имеют власти вносить изменения в таких важных делах так, как поступили; им должно скорее сохранять все в том состоянии, в каком их оставил ее отец-король, в соответствии с клятвой, данной ими перед его смертью: что они так и станут поступать, особенно в делах религии, пока ее брат-король не достигнет совершеннолетия. Они же не посмели преследовать ее, так как она была наследницей престола, но забрали у нее капелланов и наказали их за неповиновение новым законам. Леди Мария пожаловалась на это брату и написала императору о том, как обращаются с ее капелланами и слугами. Императору не понравилось, что ей не позволяют того, что позволено всем послам иностранных государей ${ }^{196}$; притом, что она - старшая сестра их короля, исповедующая католическую религию, в которой она была воспитана, и никакая другая религия ранее не была известна в Англии.

\section{Глава VI \\ Очерк царствования королевы Елизаветы. Сравнение ее с королевой Марией}

Теперь я перехожу к воспитанию королевы Елизаветы. Она не получила материнского воспитания, так как ей не исполнилось и трех лет, когда умерла ее мать. Вскоре после рождения ее провозгласили принцессой Уэльской, лишив этого титула леди

196 Католическое богослужение разрешалось в часовнях при домах послов католических стран, так как предполагалось, что там будут присутствовать только иностранцы, но не подАанные английского короля (хотя это правило неоднократно нарушалось). 
Марию $^{197}$. Вскоре после смерти ее матери, в начале июня ${ }^{198}$, король собрал ассамблею епископов и парламент, обозначив тем самым, как печалит его обида, нанесенная дочери Марии, и возвышение Елизаветы, дочери Анны Болейн. Он предпочел бы вернуться к тому, что было раньше, и установить определенное вероучение и форму богослужения ${ }^{199}$. Ибо когда правила Анна, всюду царило замешательство и распущенность, не было определено, во что следует верить, и что делать в делах религии. Ведь она (несчастная женщина) стала первопричиной схизмы и погибелью своей страны. И все же она ${ }^{200}$ была величественной и щедрой принцессой, и как сказал о ней один человек, больше годилась для величия, нежели для благочестия, и уделяла больше внимания политике, нежели религии. Ее сестра Мария ничем не уступала ей достоинствах, подобающих столь знатной принцесce, но она была на семнадцать лет старше и воспитана в добрых устоях, прежде всего в том, что касается добродетельной жизни и религии. Мистер Кемден говорит нам, что леди Елизавета читала «Общие места» Меланхтона. Я бы предпочел, чтобы она вместо того читала «Размышления», «Исповедь» и «Монологи» Блаженного Августина, а о том, как нужно жить, и делах политических - книгу святого De civitate $D e i^{201}$.

Знатная дама, хорошо знавшая Елизавету, когда той было двенадцать или тринадцать лет, говорила мне, что она была высокомерной гордячкой, и приводила примеры неприятного поведения, пятнавшего красоту ее персоны. В царствование короля

197 Акт о престолонаследии, принятый в марте 1534 г. См. примеч. 106.

198 В июне 1536 г. парламент принял новый акт о престолонаслеАии, согласно которому леди Елизавета (объявленная незаконнорожденной после аннумирования брака родителей) лишилась титула принцессы Уэльской.

199 Речь идет о "Аесяти статьях", принятых конвокацией английского Ауховенства в 1536 г. Аокумент преАставлял собой компромисс межАу протестантами (Аоктрина оправдания верой) и католиками (пресуществление, таинство исповеди, сохранение молитв святым и их изображений в церквях, молитва за умерших и т.п.).

200 В Аанном случае речь илет о Елизавете I, а не о ее матери Анне Болейн.

201 "О граде Божьем" (^ат.). 
Эдуарда доктор Лэтимер ${ }^{202}$ прочел проповедь о том, что произошло между ней и лордом-адмиралом, сэром Томасом Сеймуром, и в том была главная причина, почему парламент осудил лордаадмирала ${ }^{203}$. Был слух о ребенке, рожденном и безжалостно убитом, но нельзя было точно уставить, чей это был ребенок; есть только рассказ повитухи, которую привезли из дома с завязанными глазами и так же доставили обратно. Она ничего не увидела в доме, пока была там, только зажженные свечи. И сказала только, что ребенка родила очень красивая юная леди. Шептались об адмирале и этой леди, которой тогда было между пятнадцатью и шестнадцатью годами. Если этот рассказ правдив, то приговор был Божьей карой адмиралу, а роды — для нее, ибо она после того навсегда осталась неспособной иметь других детей. До этого, в сентябре, адмирал похоронил жену, королеву Екатерину, которая умерла родами, произведя на свет дочь ${ }^{204}$.

202 Хью Лэтимер (1487-1555) - протестантский богослов и проповедник, епископ Вустерский в 1536-1539 гг.; капемлан короля Эдуарда VI в 1547-1550 гг. В 1554 г. осужден как еретик. Сожжен на костре в Оксфорде 16 октября 1555 г.

203 Томас Сеймур, барон СаАли (1508-1549), млаАший брат мордапротектора Сомерсета, ^орА-адмирал в 1547-1549 гг. После смерти отца леди Елизавета жила в доме мачехи, королевы Екатерины Парр, и ее нового мужа, Томаса Сеймура. Именно там, в 1548 г. завязался роман меЖАу принцессой и АорАом-аАмиралом, хотя о сути их отношений АопоАлинно ничего неизвестно. После смерти жены в сентябре 1548 г. Томас Сеймур был свободен и мог жениться на принцессе. В январе 1549 г. он был арестован при попытке вломиться в покои юного ЭдуарAa VI ночью, что королевские советники расценили как попытку захватить короля и получить разрешение на брак с принцессой. Именно это стало основой обвинения в измене; 20 марта 1549 г. признанный виновным Сеймур был казнен. Елизавету и ее слуг арестовали и долго допрашивами; она и все ее Аамы настаивали на том, что ее отношения с Сеймуром оставались в рамках приличия, а об интимности и речь не шла. Тем не менее, слухи о ^юбовной связи и беременности Елизаветы разошлись Аовольно широко; именно их и воспроизвоАит КлиффорА.

204 Екатерина (Кэтрин) Парр (1512-1548), Аочь сэра Томаса Парра и МоА Грин; в первом браке (1529-1533) - жена сэра Эдварда Боро (ум. 1533), во втором (1534-1543) - Ажона Невимла, 3-го барона Лэтимера (1493-1543); шестая жена короля Генриха VIII в 1543-1547 гг. Томас Сеймур искал руки Екатерины еще в 1543 г., но ему пришлось отступить, когАа сам король саелал ей преАложение. После смерти Генриха VIII от- 


\section{Генри Клиффорд. Жизнеописание леди Джейн Дормер}

Похоже, что рогоносица не имела большого почтения к леди Елизавете, ибо в 1550 г. главного судью опекунского суда сделали графом Уилтширом ${ }^{205}$, а этот титул принадлежал ее отцу ${ }^{206}$, и его отняли у нее и его рода ${ }^{207}$. Когда же после смерти короля Эдуарда его лорды посадили на престол леди Джейн, они при этом отвергли ее и опасались только леди Марии. Я пишу все это в ответ на слова моих соотечественников, которые несправедливо возвеличивают леди Елизавету и принижают королеву Марию.

Злоключения королевы Елизаветы начались на втором году царствования ее сестры. Ее заподозрили и обвинили в соучастии в восстании сэра Томаса Уайетта ${ }^{208}$, и за это она была впервые посажена в Лондонский Тауэр и потом отправлена узницей в Ву-

ношения Сеймура и Екатерины Парр возобновились, и в апреле-мае 1547 г. (Аата неизвестна) пара тайно обвенчалась. 30 августа 1548 г. Екатерина родила Аочь Мэри и скончалась в результате родильной горячки 5 сентября того же года.

205 Уильям Полет (1485-1572) - тюдоровский юрист и придворный, занимавший в разное время посты казначея, аудитора, стюарта и мордакамергера Авора, а также, лорда-казначея и лорда-хранителя королевской печати; член Тайного совета, в 1542-1554 гг. главный судья суда по опеке. В 1550 г. Полету был дарован титул графа Уилтшира; в 1551 г. он получил более высокий титул маркиза Винчестера, а титул графа Уилтшира стал "титулом вежливости", который теперь носил наслеАник маркиза.

206 Автор путается в местоимениях. В Аанном случае "она" обозначает не Елизавету, но Анну Болейн.

207 В 1529 г. Генрих VIII даровал титул графа Уилтшира сэру Томасу Болейну. Поскольку наследник - его сын Ажордж был признан виновным в измене и казнен (1536), после смерти Болейна-старшего в 1539 г. графский титул оказался выморочным. Елизавета не могла наследовать титул Аеда, так как считалась незаконнорожденной, а ее мать - мишенной прав изменницей.

208 Сэр Томас Уайет (1521-1554), сын тюдоровского Аипломата, сэра Томаса Уайетта и Элизабет Брук. Противник брака Марии I и Филиппа II, в января 1554 г. он стал одним из заговорщиков (см. ниже), планировавших захватить королеву и посадить на престол Елизавету и графа Аевона. Уайету, еАинственному из заговорщиков, удалось поднять восстание в Кенте и повести своим отряды на АонАон. Восставшие были разгромлены у западных ворот города (ЛаАгейт). Сэр Томас был захвачен в плен, признан виновным в измене и казнен 11 апреля 1554 г. 
дсток $^{209}$. Большая часть советников, основываясь на показаниях участников и других предписаниях, старалась убедить королеву предать ее суду, однако та в доброте своей этого не допустила.

Когда в Англию приехал Филипп и был признан королем ${ }^{210}$, то, найдя леди Елизавету под арестом, он убедил королеву проявить милосердие и тем самым не только избавил ее от сурового наказания, но и обеспечил ей свободу вернуться ко двору ${ }^{211}$. В оставшиеся годы правления сестры леди Елизавета по большей части жила в собственном доме в Хатфилде ${ }^{212}$. В ее доме собирались многие люди, которых подозревали в ереси и мятеже, и лордам Тайного Совета казалось, что это нельзя больше игнорировать, но нужно расследовать и покарать виновных. Но к ней благоволили король и испанская знать, убедившие отложить расследование. Дело вышло наружу в марте следующего года, когда сэр Энтони Кингстон ${ }^{213}$, Ричард Юделл ${ }^{214}$, Джон Трокмортон ${ }^{215}$,

209 Заговорщики планировали посадить Елизавету на престол, поэтому Мария считала сестру соучастницей. В феврале 1554 г. Елизавету отправили в Тауэр; часть Совета высказывалась за ее казнь, однако 22 мая ее отправили в королевский манор ВуАсток поА Аомашний арест.

210 Король Филипп обвенчался с Марией в Винчестере 25 июля 1554 г. и был провозглашен королем Англии јure ихоris согласно условиям Акта о браке (апрель 1554, 1 Mary, с.2).

211 Елизавета вернулась ко Авору 17 апреля 1555 г.; покровительствовавший ей король Филипп преАпочитал (в отсутствие у него и Марии детей) виАеть наслеАницей именно ее, а не шотланАскую королеву Марию, права которой на английский престол отстаивал его враг - король Франции.

212 Аом в маноре ХатфилА (Хартфордшир) был построен в конце XV в. епископом Илийским Ажоном Мортоном. В XVI в. он попал в руки Генриха VIII вместе с Аругим конфискованным церковным имуществом и стал оАной из королевских резиденций. В ней провела Аетство и юность принцесса Елизавета. В 1603 г. король Яков I передал его сэру Роберту Сесиму (в обмен на манор ТеобальАс) и с тех пор он находится в собственности этой семьи.

213 Сэр Энтони Кингстон (1512-1556), тюАоровский приАворный и парламентарий, член Совета Ваммийской марки. Соучастник заговора АаАли, умер пол арестом.

214 Ричард Юваемл, младший сын сэра Уимьяма Ювделма из Уикэма, команАир гарнизона в замке Ярмут на острове Уайт. Казнен за участие в заговоре в 1556 г.

215 Ажон Трокмортон из Тортворта (ГАостершир). 
Джон Дэниэл, Уильям Стентон и другие сговорились, не без вмешательства французского посла ${ }^{216}$, ограбить сокровищницу короля, где собирались деньги для французской кампании ${ }^{217}$. Когда один из заговорщиков выдал их замыслы, некоторых арестовали и казнили, другие же бежали во Францию ${ }^{218}$. Согласно многим показаниям, леди Елизавета была соучастницей, и королевский совет хотел допросить и наказать ее, однако король вновь защитил ее от этой угрозы. Было решено, что к ней нужно отправить двух джентльменов-католиков, чтобы те оставались с ней и наблюдали все происходящее в ее доме; туда послали сэра Томаса Поупа $^{219}$ и мистера Роберта Гейджа ${ }^{220}$. Однако своим осторожным поведением, вежливостью и хитростью, а также публичным объявлением верности католической религии, леди Елизавета сумела обмануть этих дворян. Еще до конца года она втайне узнала о мистере Томасе Стаффорде, изгнаннике во Франции, который собрался, внезапно вернувшись в Англию, провозгласить себя королем (ибо он происходил из рода герцогов Бекингэмов) и жениться на леди Елизавете ${ }^{221}$. Они считали

216 Антуан Ае Ноайль (1504-1562), французский посол в Англии в 15531556 гг.

217 Заговор (1555-1556), известный по имени организатора, сэра Генри АаАли (1517-1568), млаАшего сына барона АаАли. Заговорщики планировали ограбить казначейство, а Аеньги использовать Аля того, чтобы возвести на престол Елизавету и графа Аевона.

218 Во Францию удалось бежать сэру Генри АаАли; он вернулся на родину только в 1563 г.

219 Сэр Томас Поуп (1507-1559), тюдоровский юрист и парламентарий, член Тайного Совета Марии I.

220 Сэр Роберт ГейАж из Хейлинга (1519-1587).

221 Томас СтаффорА (1533-1557) - второй сын Генри, барона СтаффорАа и Урсулы Пол, происходил от Плантагенетов, возвоАя свой роА к сыновьям ЭАуарда III: барон Стаффорд был сыном и наследником ЭАварда СтаффорАа, герцога Бекингэма (1478-1521), казненного за измену (а скорее, за то, что имел права на престол) и потомком младшего сына Эдуарда III, Хамфри, герцога Глостера; Урсула Пол была дочерью графини Солсбери (см. примеч. 182), следовательно, в числе ее предков были Ава Аругих сына Эдуарда III - ^ионел, герцог Кларенс, и ЭАмунА, герцог Йорк (преАки Аинастии Йорков). Обиженный отказом Марии I вернуть его семье титул и поместья Бекингэмов, СтаффорА присоеАинился к восстанию Уайапта, а 
себя достаточно сильными, чтобы выступить против королевы Марии. Вскоре после того мистер Стаффорд привел свой план в исполнение: 24 апреля 1557 г. он, прибыв из Франции всего с сорока людьми, взял замок Скарборо в надежде, что либо леди Елизавета пошлет свои силы забрать его оттуда, либо сама придет туда с войском. Но благодаря бдительности графа Уэстморленда $^{222}$ его захватили в плен, отправили в Лондон и обезглавили, а сторонников повесили; прочую же ответственность за это преступление возложили на леди Елизавету. Ей повезло, что как раз в это время из Фландрии в Англию вернулся король Филипп, и благодаря его заступничеству она опять избежала гибели.

Во время последней болезни королева Мария отправила лордов с поручением допросить леди Елизавету о религии. Она же ответила им: «Неужели невозможно убедить королеву в том, что я - католичка, ведь я уже столько раз объявляла об этом?», и опять поклялась в том, что является католичкой. Это - ответ словам мистера Кемдена ${ }^{223}$, и подтверждается письмом герцога Ферии королю, а герцог посещал леди Елизавету во время болезни королевы. Он заверил короля, что она исповедовала католическую религию, верила в реальное присутствие Тела и Крови Христовых в гостии и не склонна была изменять основные положения вероучения.

Правление королевы Марии началось 6 июля 1553 г. Она вернула все законы, касавшиеся религии в то положение, в каком их оставил дед, король Генрих VII, и в каком они оставались при всех христианских государях, начиная с прихода христианства в Англию. Она отменила все новые законы и нововведения, принятые в правление ее брата и отца, вернув всех к смиренному почитанию веры. Она наказала главных из тех, кто вводил новшества, и прежде всего - их главного автора, Томаса Кранме-

после его поражения бежал во Францию. В 1557 г. он попытался поднять в Англии восстание против испанцев; эти события и упомянуты в тексте.

222 Генри Невимл, 5-й граф УэстморленА (1525-1563).

223 ЗАесь КлиффорА вновь полемизирует с Кемденом ("Анналы", книга 1, глава 1), в повествовании которого и речи нет о том, что Елизавета когАа-либо была католичкой. 
$\mathrm{pa}^{224}$. Он, как предполагают, еще будучи католиком, занял кафедру и стал первым архиепископом, отошедшим от веры своих предшественников и подчинения Апостольскому престолу. Королева простила недоимки по субсидиям, объявленным в последний год царствования ее брата, давала большую милостыню бедным, простила долги тем из придворных, которые были ими сильно обременены, восстановила больше пришедших в упадок знатных домов, нежели любой другой английский государь, и принесла стране мир и изобилие. Проще говоря, в своем великодушии и добродетели она была лучшей государыней, которую когда-либо имела Англия. Тем не менее, ересь так заворожила умы некоторых ее подданных, что за пять лет ее правления она столкнулась с большим количеством открытых мятежей, нежели королева Елизавета за почти сорок пять лет ее царствования.

Королева Мария правила просто, без уловок и новшеств, суровая к отвратительным и богопротивным грешникам и строгая к мятежникам против короны, но больше по обязанности, нежели по природной склонности. Она соблюдала законы, но ее милосердие проявилось в сочувствии к герцогине Сомерсет ${ }^{225}$, сэру Джону Чику ${ }^{226}$, сэру Эдварду Монтегю ${ }^{227}$, маркизу Норх-

224 Томас Кранмер, архиепископ Кентерберийский, преАстал переА судом (светским и церковным) Аважды, в 1553 и 1555 г. и был признан виновным, соответственно, в измене и ереси. Сожжен на костре в Оксфорае 21 марта 1556 г.

225 Энн Сеймур, урожА. Стэнхоуп (1510-1587), дочь сэра ЭАварда Стэнхоупа и Элизабет Берчер, жена Эдварда Сеймура, герцога Сомерсета, мордапротектора Англии. Герцогиня была арестована вместе с мужем и оставалась в Тауэре после его казни (1551), хотя ей не предъявляли обвинения. ОсвобожАена при восшествии на престол Марии I.

226 Сэр Ажон Чик (1514-1557) - английский гуманист, глава Королевского комледжа (КембриАж), наставник принца Эдуарда, государственный секретарь (1553). Будучи протестантом, Чик преАпочел эмигрировать, когАа на престол взошла Мария I, однако был в 1556 г. арестован в НидерланАах по приказу короля Филиппа, привезен в Англию, и посажен под арест в Тауэр. Обвиненный в ереси, Чик отрекся от протестантского учения и был освобожАен.

227 Сэр ЭАварА Монтегю (1485-1557), главный судья СуАа Общих тяжб, член Тайного Совета ЭАуарАа VI; подАержал королеву АЖейн Грей (хотя и поА 
эмптону $^{228}$, сэру Генри Дадли ${ }^{229}$, сэру Фрэнсису Гейтсу ${ }^{230}$, лорду Роберту Дадли ${ }^{231}$ и к герцогу Саффолку ${ }^{232}$; все они были ее явными противниками, и большая их часть объявлена вне закона, все - враги ее веры и права на престол, однако она освободила их из Тауэра, где они пребывали в заключении.

Однако протестанты по-прежнему злоумышляли против нее и не давали ей покоя. Они писали пасквили против правления женщин $^{233}$, издавали рассуждения и выпады против религии и

Аавлением Нортумберленда) и именно поэтому в 1553 г. оказался в Тауэре, но был отпущен после выплаты большого залога.

228 Уильям Парр (1513-1571), 1-й маркиз Норхэмптон, ^орА-камергер в 1550-1553 гг.; за попытку возвести на престол Ажейн Грей был приговорен к смерти и лишился титулов, однако в конце 1553 г. был выпущен из Тауэра.

229 Не вполне ясно, кого именно имеет в виду автор. Попытку посадить Ажейн Грей на престол подАержали Ава Генри АаАли - сын барона АаАли (см. примеч. 217) и его кузен и тезка, младший сын герцога НортумберленАа (1531-1557). Оба они в 1553 г. были отправлены в Тауэр и оба получили королевское прощение несколько месяцев спустя.

230 Скорее всего, сэр Генри Гейтс (1523-1589) - придворный и парламентарий, в 1553 г. вместе с братом, сэром Ажоном Гейтсом, пытался возвести на престол Ажейн Грей. Был арестован в 1553 г., признал себя виновным в измене и приговорен к смерти, но получия королевское прощение. Его брат был казнен.

231 Роберт АаАли, 1-й граф Аестер (1533-1588), пятый сын герцога НортумберленАа, фаворит Елизаветы I, ^орА-шталмейстер (1558-1587) и распорядитель ее Авора (1587-1588). В 1553 г. вместе с отцом и братьями попытался возвести на престол Ажейн Грей. Герцог НортумберленА и муж Ажейн, ГилфорА АаАли, были казнены (см. примеч. 28 и 106), а остальные братья - Эмброуз, Роберт и Генри - были освобождены. В 1557 г. они сражались за Филиппа и Марию против французского коро^я, а в 1558 г. семье АаАли были возвращены наслеАственные права (утраченные после объявления Нортумберленда вне закона в 1553 г.).

232 Генри Грей, 1-й герцог Саффолк (1517-1554) пытался возвести дочь на престол (см. примеч. 106). Арестованный за это в 1553 г., он получил королевское прощение благодаря Аружбе жены, леди Фрэнсис (урожА. БренАОн), с королевой Марией.

233 Имеется в виду памфлет английского протестанта Ажона Нокса (15131572) “Первый трубный глас против чудовищного правления женщин" (1558), мишенью которого были королева Мария и королева - регентша Шотландии Мария Ае Гиз. 
сговаривались лишить ее власти в пользу наследницы. Bсе эти мятежные действия предпринимались во имя религии, которой не было и шести лет, религии распущенности, к которой склонялись ветропрахи, лишенной всякого воздержания ${ }^{234}$. Королеву Марию принижают, обвиняя в том, что многих сожгли в ее правление. Однако она не вводила новых законов против еретиков, а только восстановила существовавшие ранее, те, что действуют в церкви Господней с момента принятия Англией христианства ${ }^{235}$. А когда один человек обвинялся в ереси, измене или уголовном преступлении, по воле королевы применялся закон, поскольку ересь - прямое преступление против Бога.

Прожив тридцать семь лет девственницей, королева Мария ради блага страны, чтобы оставить потомство, вышла замуж за знатнейшего государя христианского мира, который принес английской короне богатство, честь и лучшие союзы в Европе. Посмотрите, однако, какие за этим последовали заговоры и мятежи: восстание сэра Томаса Уайетта на востоке Англии ${ }^{236}$; сэра Питера Кэрью, сэра Гэвина Кэрью и сэра Томаса Денни — на западе $^{237}$; сэра Джеймса Крофта и прочих — в Уэльсе ${ }^{238}$; герцога

234 Имеется в вилу отсутствие в церкви Англии правила целибата.

235 Парламентский акт 1554 г. (1 \& 2 Ph. \& М. с.6) восстановил отмененные при Генрихе VIII и Эдуарде VI статуты о преследовании и наказании еретиков 1382 (5 Ric. 2 Stat. 2, с.5), 1401 (2 Hen.4 с.15) и 1414 (2 Hen. V St. 1, с. 7).

236 В конце января 1554 г. сэр Томас Уайат поднял восстание против коромевы в Кенте (см. примеч. 208).

237 Сэр Питер Кэрью (1514-1575) - Аворянин из Аевона, парламентарий и солдат; сэр Гэвин Кэрью (1503-1585), его АяАя, шериф Аевона; Томас Аенни - видимо, млаАший брат сэра Энтони Аенни, Аворянина королевской опочивальни и члена Тайного Совета Генриха VIII. Bсе трое попытамись одновременно с Уайеттом поднять в январе 1554 г. восстание в Аевоне, однако потерпели неудачу. Гэвина Кэрью и Аенни арестовали сразу после этого и в 1555 г. отпустили после выплаты большого залога; Питер Кэрью бежал во Францию и был в 1556 г. арестован в НидерланАах вместе с сэром Ажоном Чиком (см. примеч. 226). Освобожден из-под ареста в конце того же года.

238 Сэр Ажеймс Крофт (1517-1590), тюдоровский приАворный и Аворянин Ваммийской марки. Его план поднять в 1554 г. восстание в Уэльсе и Херефордшире был раскрыт; Крофт преАстал переА судом, был признан ви- 
Саффолка (уже получившего прощение) - в Лестершире ${ }^{239}$. Затем, после этого, заговоры графа Девоншира ${ }^{240}$, сэра Николаса Трокмортона $^{241}$ и других. И секретаря времен короля Эдуарда, Уильяма Томаса, умышлявшего убить королеву; перед казнью он объявил, что умирает за свою страну ${ }^{242}$. После этого были Юделл, Трокмортон и прочие, и Томас Стратфорд, о которых я уже упоминал раньше.

Королева Елизавета унаследовала королевство 17 ноября 1558 г.; король Филипп находился тогда во Франции под Дурле ${ }^{243}$. Новые советники убедили ее вернуть себе духовную власть и юрисдикцию $^{244}$. Возможно, что ее именно убедили, учитывая клятвы, данные ею в правление королевы Марии советникам, посланным допросить ее, а также слова, сказанные ею герцогу Ферии, послам и другим людям в нескольких случаях, и почитание, оказываемое ею Святому Кресту, Благословенной Деве Марии и святым. Она умерла, имея перед собой золотое распятие, так что

новным в измене и приговорен к смерти, однако в 1555 г. получил коромевское прощение.

239 Попытка герцога Саффолка поднять в 1554 г. восстание в Лестершире, после того как он всего год назад получил королевское прощение (см. примеч. 185 и 204), на этот раз привела его на плаху. Казнен 23 февра^я 1554 г.

240 Имеются в виду заговоры Уайетта и АаАли (1554 и 1555 гг.), ставившие своей целью возвести на престол графа Аевона и Елизавету. См. примеч. 208 и 217.

241 Сэр Николас Трокмортон (1516-1571) - тюдоровский парламентарий и Аипломат. В 1554 г. был арестован за соучастие в заговоре Уайетта, предстал перед судом и был оправдан. В 1555 г. его освободили из Тауэра, однако в 1556 г. Трокмортона заподозрили в причастности к заговору АаАли, и он бежал во Францию. В 1557 г. он получил королевское прощение и сражался за Филиппа и Марию поА Сент-Квентином.

242 Уимьям Томас (ум. 1554) - гуманист, клерк Тайного Совета при Эдуарда VI. Участник заговора Уайетта; после подавления восстания в феврале 1554 г. пытался бежать в Уэльс, но был арестован и 8 мая 1554 г. предстал перед судом, приговорившим его к смерти за измену. Казнен 18 мая 1554 г.

243 Аурлер. См. примеч. 140.

244 Елизаветинский акт о супрематии (1559: 1 Eliz 1 с 1) провозгласил королеву “верховной распорядительницей supreme governor) церкви Англии. 


\section{Генри Клиффорд. Жизнеописание леди Джейн Дормер}

доктор Барлоу ${ }^{245}$ заявил: она умерла паписткой. Кажется, однако, что люди, стремившиеся установить новую религию, следовали своим убеждениям и мало-помалу перевернули все с ног на голову. Благодаря им королева Елизавета согласилась издать такие суровые законы против католиков, какие ни один государь никогда не издавал против преступников любого толка. Свидетельство тому - находящиеся в силе статуты ${ }^{246}$, казни многих священников и страдания бесчисленных подданных за это дело.

До коронации королева велела всем епископам молчать и не проповедовать. После заседаний парламента все неприсягнувшие 247 были лишены сана, приходов и постов церковных и светских и отправились в тюрьму. В Англии сместили четырнадцать епископов, ученейших прелатов, в Ирландии - десять; двенадцать настоятелей соборов, пятнадцать глав коллегий, шесть аббатов, двенадцать архидиаконов, сто шестьдесят священников, а также мистера Шелли, приора ордена Св. Иоанна Иерусалимского ${ }^{248}$.

Книгу Общих молитв, их новый служебник, составили Паркер, Гриндал, Хорн, Уайтхед, Билл и сэр Томас Смит ${ }^{249}$. Слыхано

245 Уимьям Барлоу (ум. 1613) - английский богослов и полемист, настоятель Честерского собора, епископ Рочестерский (1605-1608) и ^инкольнский (1608-1613).

246 Имеются в виду принятые английским парламентом во второй половине XVI в. антикатолические статуты 1559, 1563, 1571, 1581, 1585, 1593 гг., запрещавшие католическое богослужение и приравнивавшие деятельность католических миссионеров к государственной измене, а также ввоАившее штрафы за отсутствие на протестантской воскресной митургии.

247 T.е., не признавшие королеву главой церкви.

248 Ричард Шемли (1513-1589) - последний приор Ордена Св. Иоанна Иерусалимского в Англии. Смерть Марии I застала Шемли в Брюсселе. В 1559 г., еще до официальной смены вероисповедания в Англии, он был отправлен к Фердинанду I в качестве посланника новой королевы, и больше в Англию не возвращался. Он жил в Испании, на Мальте и в Итамии. Умер в Венеции.

249 Члены комиссии по пересмотру служебника (1559): Мэтью Паркер (1504-1575) - архиепископ Кентерберийский в 1559-1575 гг.; ЭАмунА Гриндел (1519-1583) - епископ Аондонский (1559-1570), архиепископ Йоркский (1570-1576) и Кентерберийский (1576-1583); Роберт Хорн (1510-1580), епископ Винчестерский в 1560-1580 гг.; АэвиА УайтхеА (1492-1571) - протестантский богослов; Уимьям Бимл (1505-1561) протестантский богослов, настоятель Вестминстерского собора в 1560- 
ли это, чтобы в христианском королевстве порядок богослужения определялся без согласия и помощи епископов? Но это совершили выскочки и миряне, впоследствии сделавшие себя епископами. В дебатах, которые воспоследовали, председателем назначили сэра Николаса Бэкона, простого мирянина, которого потом назначили лордом-хранителем печати ${ }^{250}$. Он, будучи знатоком законов, а не богословом, стал одним из главных советчиков, убедивших королеву избрать этот образ действий и изменить религию.

Конец добрых епископов был таков. Доктор Скотт, епископ Честерский умер в изгнании в Лувене ${ }^{251}$; Голдуэлл СентАсафский — в Риме ${ }^{252}$; Пейт Вустерский подписал каноны Тридентского Собора от имени английского клира и не вернулся в Англию $^{253}$; доктор Оглторп Карлайлский, короновавший короле-

1561 гг.; сэр Томас Смит (1513-1577) - ученый, протестантский богослов и Аипломат. Все, кроме Смита, были Ауховными мицами, оАнако КлиффорА, обозначая их мирянами, подчеркивает свое непризнание протестантской церковной иерархии.

250 Сэр Николас Бэкон (1510-1579) - тюАоровский юрист, ^орА-хранитель королевской печати в 1558-1579 гг.

251 Катберт Скотт (ум. 1564) - Аоктор богословия, профессор КембриАжского университета, епископ Честерский в 1556-1559 гг. В 1559-1563 гг. был под арестом в Тауэре и тюрьме Флит; сумел бежать в Нидерланды; умер в Аувене.

252 Томас Голауэмм (1501-1585) - выпускник ОксфорАского университета, капемлан кардинала Пола в 1539-1553 гг., епископ Сент-Асафский в 1555-1559 гг.; эмигрировал в Италию, гАе с 1561 г. был главой обители театинцев в Риме. Участвовал в заседаниях Тридентского собора d 1563-1564 гг.; в 1560-х гг. викарий Карло Борромео, архиепископа Миланского. Умер в Риме.

253 РичарА Пейт (ум. 1564) - католический богослов, архиАиакон Линкольского собора в 1528-1540 гг., в 1533-1540 гг. посол при Аворе императора Карла V, затем жил в изгнании до 1553 г. Назначен папой на Вустерскую кафедру в 1542 г. (за что в Англии его объявили вне закона). Участвовал в работе Тридентского собора в 1547, 1549 и 1551 гг. Вернулся на родину в 1554 г. и Ао 1559 г. был епископом Вустерским. В 1559 г. лишился кафедры и был арестован, затем бежал в ^увен и умер в изгнании. 


\section{Генри Клиффорд. Жизнеописание леди Джейн Дормер}

ву, скоропостижно скончался вскоре после лишения сана ${ }^{254}$; знаменитый ученостью Тансталл умер узником в Лэмбете ${ }^{255}$; Бурн Уэллский стал узником Кэрью, настоятеля Часовни Св. Георгия $^{256}$; Терлби Илийского отправили в Тауэр, а потом в Ламбет, где он и умер ${ }^{257}$; аббат Фекэм, епископ Уотсон, епископ Уайт и епископ Боннер умерли в заключении ${ }^{258}$; а приор Шелли - в изгнании $^{259}$. Так свершилось падение католического клира, вещь невероятная для потомков.

Королева взошла на престол, будучи двадцати пяти лет отроду, прекрасная госпожа благородной наружности. Но ее невозможно было убедить выйти замуж, а на могиле своей она приказала написать, что жила и умерла девственницей. Король Генрих IV Французский, смеясь, сказал, что мир ни за что не поверит этому, не поверят и ее многочисленные фавориты, например, Пикеринг, который был у нее еще до коронации, так что все

254 Оуэн Оглторп (ум. 1559) - епископ Карлайлский в 1557-1559 гг.; короновал Елизавету І, так как все остальные епископы отказались участвовать в церемонии. В 1559 г., незадолго Ао смерти, бы^ ^ишен епископской кафедры.

255 См. примеч. 132.

256 Гилберт Бурн (ум. 1569) - епископ Уэмлский в 1554-1559 гг.; после мишения кафедры был арестован (1560) и почти 10 лет провел в Тауэре и Аругих ^онАонских тюрьмах. НезаАолго Ао смерти был отправлен поА Аомашний арест в резиденцию Ажорджа Кэрью (1498-1583), настояте^я Часовни Св. Георгия в ВинАзоре.

257 Томас Терлби (1506-1570), епископ Илийский в 1554-1559 гг. Аишен кафедры в 1559 г., в 1560-1564 гг. находился под арестом в Тауэре, затем был переведен в ^амбет под надзор архиепископа Кентерберийского (1564-1570).

258 Ажон Фекенхэм (1515-1584) - настоятель собора Св. Павла в Лондоне (1554-1559), послеАний аббат Вестминстерского аббатства (15541560), в 1560-1574 гг. был под арестом в Тауэре, а в 1580-1584 гг. в замке Уисбеч (близ Или); Томас Уотсон (1515-1584) - епископ ^инкольнский в 1557-1559 гг., с 1559 г. по арестом в Тауэре (начало 1560-х гг., 1570-1571), в резиденциях епископов Рочестерского и Илийского, и в замке Уисбеч (1580-1584); Ажон Уайт (1510-1560), епископ Аинскольский (1554-1556) и Винчестерский (1556-1559), в 1559 г. был отправлен в Тауэр, гле и умер; о Боннере см. примеч. 131.

259 См. примеч. 248. 
считали: он должен на ней жениться ${ }^{260}$. Не поверили бы и Лестер $^{261}$, Пакингтон ${ }^{262}$, Хаттон $^{263}$, Рэли $^{264}$ и Эссекс ${ }^{265}$. Тем, что можно о ней рассказать, можно заполнить тома. В Анналах ее жизни мистер Кемден сделал это весьма избирательно, во многих местах опуская то, что должен был бы рассказать, особенно о католиках. Совесть может напомнить ему, что он не выполнил обещанное в послании к читателю, особенно в том, что касается процесса, приговора и казни королевы шотландцев, матери Его Величества и ближайшей кровной родственницы самой королевы Елизаветы ${ }^{266}$; эта смерть стала ее несмываемым позором. Ее счастье восхваляется до небес льстивыми еретиками и теми, кто не знает и не хочет знать о том, что происходило в ее царствование, до него, и в момент ее смерти. Ради ее интересов погибли многие в правления ее брата и сестры; умы подданных отвлекались множеством сект и раздоров в религии; обильно проливалась кровь католических священников, благородных и честных людей; подданных постоянно подавляли субсидиями и налогами; она оказывала помощь мятежникам против своих природных

260 Сэр Уимьям Пикеринг (1516-1575) - приАворный и Аипломат; в 1559 г. считался оАним из поклонников королевы Елизаветы, искавших ее руки.

261 Роберт АаАли, граф Аестер. См. примеч. 231.

262 Сэр Ажон Пакинпон (1549-1625) - елизаветинский приАворный; в начале 1570-х гг. прославился как один из поклонников королевы.

263 Сэр Кристофер Хаттон (1540-1591) - елизаветинский прияворный, королевский фаворит, лорА-канцлер в 1588-1581 гг.

264 Сэр Уолтер Рэли (1554-1618) - приАворный, солАат и путешественник, королевский фаворит.

265 Роберт Аеверо, 2-й граф Эссекс (1565-1601) - фаворит и роАственник королевы Елизаветы (правнук Мэри Болейн и, вероятно, Генриха VIII), морА-шталмейстер в 1587-1601 гг.

266 Мария Стюарт (1542-1587), королева Шотландии в 1542-1567 гг., в 1568-1587 гг. находилась в Англии под арестом (обвиненная в причастности к убийству мужа, Генри Стюарта, лорАа Аарнли). В 1586 г. преАстала перед судом в Англии по обвинению в соучастии в заговоре Бабингтона (ставившего своей целью убить королеву Елизавету и возвести на английский престол Марию). Признана виновной, приговорена к смерти и казнена 8 февраля 1587 г. 
государей, например, голландцам и гугенотам ${ }^{267}$. Людям навязали несправедливый закон о супрематии, а отказ принести присягу считался изменой, однако ее не навязывали знатным дворянам $^{268}$. Королю Испании наносились оскорбления, например, захват его сокровищ ${ }^{269}$, разрешение знатным дворянам быть пиратами и грабителями ${ }^{270}$, позволение Дрейку и другим грабить его корабли, штурмовать города и захватывать его людей ${ }^{271}$, причем она сама первая дала повод к войне, выступая против того, кто трижды спас ее жизнь и свободу.

Перейдем же к ее смерти. Она проистекла из странной меланхолии, ставшей, скорее всего, следствием размышлений об уже перечисленных делах. Постарев, она утратила свою красоту. Королева Елизавета подозревала, что многие среди знатнейших ее лордов смотрели в сторону Шотландии. Эти соображения уничтожили все ее великодушие. Пренебрежение служением Господу заставило ее перед смертью погрузиться в тоску и глубокую ме-

267 Английское правительство оказывало тайную подАержку восставшим против Филиппа II гоммандским протестантам еще с 1568 г., а в 1584 г. было подписано соглашение об оказании им военной помощи, что привело к войне Англии и Испании (1585-1604). В 1562 г. было также подписано соглашение с мидерами французских гугенотов, которым англичане оказывали военную помощь в кампании 1562-1563 гг. В 1590-х гг. английские отряды воевали во Франции на стороне Генриха Наваррского против испанских войск герцога Пармского.

268 Имеется в виду Акт о супрематии 1559 г., предписывавший всем поААанным по требованию приносить присягу королеве как главе церкви Англии. Это предписание не распространя^ось на титулованную знать, в числе которой было немало католиков.

269 В 1569 г. английское правительство задержало в Плимуте испанские корабли, укрывшиеся там от шторма. Корабли везли золото, предназначавшееся Аля платы солдатам герцога Альбы в Нилерландах. Захват груза привел к серьезному кризису в англо-испанских отношениях.

270 Получавшие королевские патенты английские моряки в 1560-1570-х гг. официально занимались торговлей, но на практике - незаконной работорговлей и пиратством, что вызывало многочисленные конфликты с испанцами в Карибском бассейне.

271 В ходе своего кругосветного путешествия 1577-1580 гг. флотилия Фрэнсиса Арейка разграбила испанские города на тихоокеанском побережье Южной Америки (Вальпараисо и др.), а также захватила в ^име галеон с золотом и Арагоценностями, предназначавшийся Аля отправки в Испанию. 
ланхолию. Еще до болезни, находясь в Уайтхолле ${ }^{272}$, королева испытала ослабление чувств, аппетита и упадок сил. Ее мучили пугающие видения; оттуда она уехала в Ричмонд ${ }^{273}$ и там слегла. Она сказала одной леди, из тех, кто все время находилась с ней ${ }^{274}$, что видела вокруг себя яркое пламя, и спросила даму, не видела ли та снов той ночью. Когда болезнь усилилась, королева, полностью одетая, просидела в кресле два дня и три ночи, и никто не мог убедить ее лечь в постель, поесть или попить. Только лордуадмиралу $^{275}$ однажды удалось убедить ее выпить немного бульона; никому другому она не говорила ни слова; ему же она тихо сказала: если бы он только знал, что она видит, лежа в постели, он не стал бы ее уговаривать. Приказав остальным лордам удалиться из ее опочивальни, она приказала лорду-адмиралу остаться и, покачав головой, жалобным голосом сказала ему: «Милорд, на моей шее железные цепи». Он ответил, что ей не хватает смелости, на что она заметила: «Я связана, и со мной все изменится».

Под сиденьем кресла королевы обнаружили карту (даму червей), сквозь голову которой был вбит гвоздь; дамы не посмели вынуть его, считая все это колдовством. Так королева, уже в состоянии неизлечимой болезни, провела несколько дней в постели. К ней послали архиепископа Кентерберийского ${ }^{276}$ и других прелатов, но она рассердилась, увидев их, гневно отругала и

272 Аворец Уайтхом^ (межАу Аондоном и Вестминстером) - главная резиАенция английских королей в 1530-1694 гг.

273 Аворец в Ричмонде - резиденция английских королей в XVI-XVII вв. Был построен Генрихом VII ок. 1501 г.; пришел в запустение и был фактически разобран в середине XVII в. ^юбимый замок королевы Елизаветы.

274 Рассказ о смерти Елизаветы основывается на воспоминаниях Элизабет Саутуэм^ (1586-1631), Аочери сэра Роберта Саутуэмла и Элизабет ХоварА. В 1599-1603 гг. Элизабет Саутуэмл была фрейлиной королевы Елизаветы, находилась рядом с ней переА смертью и впослеАствии составила об этом записки. В 1605 г. Элизабет бежала из Англии вместе с сэром Робертом АаАли (незаконнорожденным сыном графа лестера). Пара обратилась в католичество и вступила в брак с особого разрешения папы (т.к. АаАли уже был женат в Англии). Супруги жили во Флоренции.

275 Чарльз Ховард; см. примеч. 136.

276 Ажон Уитгифт (1530-1604), архиепископ Кентерберийский в 15831604 гг. 
выгнала прочь. Потом она заявила лорду-адмиралу, что архиепископ позволил себе наивысшее оскорбление, какое только можно нанести государю, а именно, объявить ей смертный приговор, как будто бы она прожила жизнь атеисткой. Лорды предложили прислать к ней других прелатов, она же ответила, что не хочет этих невежественных бродяг. Так что никто не приходил к ней до тех пор, пока она не лишилась чувств, и лишь в последний момент, находясь рядом с ней, произнесли слова молитв. Таков был конец этой королевы после сорока четырех лет, четырех месяцев и нескольких дней правления, прошедшего в великой мирской славе и удовольствиях. Никто не слышал, чтобы в своей болезни она сказала: «Помоги мне Господь!», произнесла слова молитвы или призвала Бога и просила о Его милости.

Теперь же, после долгого отступления, настало время вернуться к госпоже герцогине.

\section{Глава VII \\ Прибытие в Англию герцога Ферии. \\ Его история и характер. Он женится на Джейн Дормер}

Когда король Филипп, принц Испании, прибыл в Англию, чтобы жениться на королеве Марии, его сопровождали многие знатные особы и благородные дворяне. Среди них был дон Гомес де Фигероа и Кордоба, граф, а впоследствии - герцог Ферия ${ }^{277}$, знатный сеньор и испанский гранд, один из советников короля, который проявлял к нему большую благосклонность. Этот человек начал испытывать особую привязанность к герцогине и (будучи испанцем) пожелал узнать о ее рождении, родстве и знатности. Узнав, что по древности рода и почетным титулам ее род не ниже его собственного, он решился просить ее руки (хотя испан-

277 Гомес Суарес де Фигероа и Кордоба (1523-1571), граф, а с 1567 г. герцог Ае Ферия, второй сын Аоренсо Суареса де Фигероа, графа Ферии, и Катамины Фернандес де Кордоба и Энрикес, маркизы де Приего; в 1554-1555 гг. губернатор Милана; капитан гвардии короля Филиппа в Англии, в 1557 г. участвова^ в сражении при Сент-Кантене; в 1558-1559 гг. посол Филиппа при английском Аворе; по возвращении в Испанию - королевский камергер и член Совета Войны; в 1571 г. был назначен губернатором НиАерландов, но умер, не успев занять Аолжность. 
ские гранды редко женятся на дамах не их круга и нации); его к тому побудил фавор, в каком она была у королевы, а также ее красота и изящество. Это чувство основывалось на ее добродетели в той же мере, как и на редкой красоте (герцогу было тогда тридцать восемь лет), и, учитывая все свойства натуры этой прекрасной дамы, счастлив был бы тот, кому она досталась. То, что не только знатные лорды ее собственного королевства, но и дворяне других наций искали ее руки, есть явный довод, подтверждающий ее достоинства, скромное и достойное поведение. А поскольку именно иностранцу посчастливилось получить ее руку, он тем самым был в еще большей степени обязан почитать ее, ведь она ради него оставила свою страну и друзей и пренебрегла другими женихами; все это, как я уже отмечал, подтвердил сам герцог в своем завещании. В нем он просил короля дать согласие на то, чтобы герцогиня, леди Джейн Дормер, его законная и возлюбленная жена, могла выбрать себе из его владений два города, с юрисдикцией гражданской и уголовной, а также всеми рентами и доходами, и пользоваться ими на протяжении своей жизни. «Я обязан (сказал он) просить об этом Ваше Величество, потому что герцогиня пренебрегла лучшими женихами своей страны и доверилась мне, чужеземцу, ее слуге и вассалу». Таковы слова герцога в его завещании. В выборе супруга, как во всей своей жизни, леди Джейн Дормер руководствовалась примером добродетели и разумения ее госпожи, королевы. Ибо королева по нижайшей просьбе всего королевства и по суждению ее мудрого католического совета, предполагая поступить наилучшим образом для общего блага, решилась выйти замуж, рассудив, что все дела, касающиеся религии и управления, можно лучше разрешить через установление прочного наследования престола. И хотя ей предлагали многих, и в самом королевстве, и вне его, но, в конце концов, она решила выбрать в мужья принца Филиппа Испанского, сына императора Карла $\mathrm{V}^{278}$ как самого знатного и выгодного для королевства. Так и герцогиня предпочла знатным лордам своей страны чужестран-

278 На момент свадьбы Филипп (1527-1598) был королем Неаполитанским (1554-1598). После отречения Карла V от престола он стал королем Испании (1556-1598). 


\section{Генри Клиффорд. Жизнеописание леди Джейн Дормер}

ца из Испании, герцога Ферию. Король и королева с радостью согласились на этот брак, однако она не соглашалась утроить свадьбу до того, как король вернется из Фландрии, куда он отправился из-за боевых действий, которые шли на границе с Францией, а с ним уехал и герцог ${ }^{279}$.

Тем временем королева смертельно заболела, и король послал к ней с визитом герцога, но сам не вернулся. После смерти и похорон королевы герцогиня уехала к бабушке, которая тогда жила в своем доме в Савое 280 . Там, когда герцог выразил настоятельное желание заключить брак, они и обвенчались в часовне Савойского дворца 29 декабря, в праздник достославного мученика Св. Фомы Кентерберийского ${ }^{281}$. Дяди Джейн, сэр Генри Сидни ${ }^{282}$ и граф Сассекс ${ }^{283}$, хотя и с большим недовольством, дали согласие на брак: им не хотелось, чтобы всеми любимая племянница оставляла страну, родных и друзей ради жизни с чужестранцем в стране столь далекой от них и со столь отличным от их климатом. Но так устроил Господь, и герцог почел за счастье стать мужем той, чьи достоинства и добродетель ценил, по его собственным словам, превыше всех царств и должностей мира.

279 Граф Ферия сопровожАал короля Филиппа в качестве капитана его гварАии. Во время своего английского правления Филипп АважАы уезжал в Нилерланды: с сентября 1555 по март 1557 гг., и с июня 1557 г. В тексте речь илет о втором отьезАе, когАа Филиппа сопровожАали к СентКантену английские отряды.

280 Савой - место на Стренде (сейчас - улица в Аондоне, в XVI в. - Аорога межАу АонАоном и Вестминстером), на котором в XIII-XIV в. стоя^ Аворец, построенный графом Савойским (отсюда и название). Аворец был разрушен во время крестьянского восстания 1381 г., но местность сохранила название. Генрих VII построил зАесь странноприимный Аом. ^еАи Аормер жила рядом с ним, а ее внучка обвенчалась там в часовне.

281 Св. Фома (Томас) Бекет (1119-1170), архиепископ Кентерберийский в 1162-1170 гг. Убит по приказу короля Генриха II и канонизирован в 1173 г.; один из самых почитаемых святых средневековой Англии, патрон Лонаона.

282 См. примеч. 41.

283 Томас Рэлклиф,3-й граф Сассекс (1525-1583), был Аальним родственником Аормеров: его род по женской минии также восходия к Ричарау Вудвилу, графу Риверсу (см. примеч. 15). 
Герцог был послом и представителем своего короля и выполнял свои обязанности доблестно и достойно, как верный и благочестивый сын католической церкви. Ведь когда новая королева начала менять и извращать богослужение, отменять древние законы о религии, восстановленные ее покойной сестрой, то в день коронации $^{284}$ герцог, которого сама королева и ее совет настоятельно приглашали там присутствовать (как он присутствовал в день ее торжественного въезда в Лондон, когда она была провозглашена королевой) ${ }^{285}$, спросил, будут ли в ходе коронации совершены все обычные церемонии, какие происходят при коронации других христианских государей, согласно правилам католической церкви и древним обычаям католических государей этого королевства. Поняв из их ответа, что в церемонию будут внесены изменения, он отказался им помочь, публично ли в церкви, или же втайне, в месте, которое для него обеспечат, так как не мог своим присутствием признать действие, не сочетавшееся с почитанием католической церкви и соблюдением ее обычаев.

Примерно в это время в Англию прибыл посол-резидент, епископ Аквильский ${ }^{286}$. Король, все еще находившийся во Фландрии, послал за герцогом Ферией, который перед отъездом из Англии по настоянию жены ходатайствовал перед королевой позволить ему забрать с собой тех монашествующих ее королевства, мужчин и женщин, которые захотят поехать с ним; он же обязывался доставить их в те места, где они смогут свободно служить Богу и соблюдать устав своего ордена. Прежде этого он пытался всеми возможными способами убедить королеву и ее новых советников не изменять католической религии, которую она публично исповедовала, унаследовав корону, но сохранить в силе все защищавшие ее законы, обещая властью короля устранить все затруднения и любое сопротивление. Не все было напрасно, ибо ему давали вежливые ответы, а затем поступали совсем по-другому. Он получил разрешение в ответ на просьбу

28415 января 1559 г.

28514 января 1559 г.

286 Альваро де Квадра (ум. 1564), епископ Аквильский (1553-1561), испанский посол в Англии (1559-1563). 


\section{Генри Клиффорд. Жизнеописание леди Джейн Дормер}

увести монашествующих из Англии, хотя и с большим трудом, преодолев затруднения, созданные некоторыми из главных советников, распускавших слухи и устроивших много препятствий, говоривших королеве о многих бедствиях, какие могли воспоследовать для нее и ее дел от такого разрешения. Тем не менее, герцог не сдался (таковы были его отвага и рвение), постоянно напоминая королеве о ее обещании, и собрал так много из них, сколько сумел, в своей резиденции - Дарэм Хаусе ${ }^{287}$, и там содержал их, пока не получил разрешение на их отбытие во Фландрию. Среди них были три конвента: картузианцев из Шина, которые по милости Божией до сих пор сохранились как единая обитель в Мехельне в Брабанте ${ }^{288}$; монахинь-бригеттинок из обители в Сионе; эта община также сохранилась и состоит из многих знатных дам и блаженных сестер, живущих в Лиссабоне в Португалии ${ }^{289}$; третьим же была обитель доминиканских монахинь из Дартфорда ${ }^{290}$, их, однако, было немного, и их вскоре распределили по монастырям их собственного ордена. Когда же герцог выехал из Англии, что произошло в конце мая 1559 г., с ним было много священников, а впоследствии в свите герцогини за ними последовали и многие другие. Прибыв к королю, он ходатайствовал перед ним за этих людей, моля о его благосклонности и защите; король обещал им это в своей любви и благочестии, как и подобает великому католическому государю.

287 ЛонАонская резиденция епископа Аарэмского, построенная ок. 1345 г. в 1532 г. была конфискована Генрихом VIII и впоследствии была в распоряжении королей. В 1559 г. - Аом испанского посла в АонАоне.

288 Картузианский монастырь, основанный в 1414 г. в королевском маноре Шин (РичмонА). Распущен в 1539 г. и воссоздан в 1555 г. Покинувшие Англию в 1559 г. монахи Аолго скитались по Нилерландам, гонимые с места на место войной - из Брюгге (1559-1578) в Намюр или Ауэ (1578), ^увен (1578- ?), Антверпен (?-1591), Мехельн (1591-1626) и лишь в 1626 г. осели в Ньивпорте. Обитель была распущена после реформы императора Иосифа II в 1783 г.

289 См. примеч. 96.

290 Конвент Аоминиканских монахинь был основан в Аартфорде (сейчас восточный АонАОН) в XIV в.; в 1539 г. община была распущена и воссозАана в 1555 г. 
Герцог оставил жену в своем доме в Лондоне, и она оставалась там почти до конца июля. Тогда в Лондон прибыл дон Хуан де Айала, посланный за ней королем и герцогом ${ }^{291}$. Герцогиня немедленно начала собираться в дорогу; 24 июля она отправилась попрощаться с королевой Елизаветой. Она ожидала в парадном покое, когда королева позовет ее, и долго оставалась на ногах, так что испанский посол начал сердиться, ведь она была уже на седьмом месяце беременности. Епископ громко заявил, что, учитывая, кто она такая, и ее беременность, герцогине не подобает стоять и ждать, и стал уговаривать ее сесть на стул королевы. Когда королева Елизавета узнала об этом, то немедленно вышла к ней. Спустя два дня после прощания герцогиня отправилась в Дувр, откуда ей предстояло отплыть. Ее сопровождало множество знатных дворян и дам, родственников и друзей, и среди них - господин епископ, постоянный посол, которому король дал особое распоряжение позаботиться о ней. Вместе с нею оправилась добрая леди, ее дорогая и любимая бабушка, воспользовавшаяся возможностью уехать туда, где она могла свободно и безопасно служить Богу, имея для того возможность и средства. Герцогиню сопровождали шесть ее дам, все - дочери знатных и влиятельных джентльменов. Одна была сестрой лорда Харрингтона, двоюродного брата герцогини ${ }^{292}$; другая сестрой сэра Эдварда Страдлинга ${ }^{293}$; еще одна - сестра королевского фаворита, сэра Уильяма Пикеринга ${ }^{294}$; еще одна - госпожа Пастон, которая впоследствии, вернувшись в Англию, стала женой сэра Генри Ньютона из Глостершира и дамой опочиваль-

291 Аон Хуан Ае Айала - испанский Аипломат, оАин из королевских секретарей.

292 Маргарет Харинттон, Аочь сэра Ажеймса Харинптона и Люси СиАни (сестры Мэри СиАни, матери Ажейн Аормер), старшая сестра барона Ажона Харингтона (1540-1613). В Испании Маргарет Харингтон стала женой Аворянина из свиты Ферия, Бенито Ае Сиснероса.

293 Аамасин СтраАлинг, Аочь сэра Томаса СтраАлинга (ум. 1571) и Кэтрин Гемедж, сестра сэра ЭАварда СтраАлинга (1529-1609). Умерла в 1567 г. в Испании.

294 Энн Пикеринг, младшая сестра известного елизаветинского приАворного сэра Уильяма Пикеринга (см. примеч. 234). Вышла замуж за Роже Ае ^а Ривьера. 


\section{Генри Клиффорд. Жизнеописание леди Джейн Дормер}

ни королевы Елизаветы, и других ${ }^{295}$; и с ними госпожа Кларенсиус, служившая королеве Марии с ее детства и была ее самым доверенным лицом; женщина, уважаемая и любимая королевой, провела остаток жизни в доме герцогини ${ }^{296}$. Кроме того, священники, получившие разрешение отбыть, многие джентльмены, получившие ее покровительство, смогли уехать туда, где могли жить в соответствии со своим желанием служить Господу.

По прибытии в Дувр она попрощалась с друзьями, среди которых были граф Сассекс и сэр Генри Сидни, а на следующий день после обеда отплыла в Кале, куда и прибыла через несколько часов. Ее встречал господин Гурден, губернатор Кале; посетить ее там прибыл также и губернатор Булони. В городе Кале герцогиня отдохнула день и две ночи, а губернаторы устроили в ее честь празднество и развлечения, затем она поехала в Гравлин, а оттуда в Дюнкерк, на землях короля Испании. В обоих городах ее ждали пиршества и торжественные встречи под пушечные залпы. Губернаторы встречали ее вместе с капитанами, а солдаты маршировали строем, оказывали ей все знаки приветствия, подносили дары, как обычно делают в тех местах в отношении знатных особ.

Из Дюнкерка она поехала в Ньивпорт, а оттуда - в Брюгге, где отдыхала несколько дней. Туда приехал приветствовать ее сам герцог, ее супруг, и дон Луис Мендес ${ }^{297}$, которого король послал нанести ей визит и приветствовать ее в его владениях. Также туда приехал дон Антонио де Толедо, брат герцога Альбы, командор ордена Св. Иоанна и великий приор Кастилии ${ }^{298}$. В

295 Кэтрин Пастон (1547-1615), Аочь сэра Томаса Пастона и Ангес ^и. Вернулась в Англию в середине 1570-х гг., с 1576 г. - фрейлина, затем дама свиты Елизаветы І. В 1578 г. она вышла замуж за сэра Генри Ньютона.

296 Сьюзен Уайт (ок. 1510-ок. 1566), жена Томаса Тонга, гербового короля Кларенсье; известна как госпожа Кларенсье или Кларенсиус. Служила в свите принцессы Марии с 1525 г. и провела с ней практически всю жизнь. Самое близкое и доверенное лицо королевы.

297 Аон Луис Мендес Ае Аро, младший брат маркиза Аель Карпио, придворный, приближенный и советник короля Филиппа II.

298 Антонио Альварес Ае Толедо (ум. после 1571), рыцарь Ордена Св. Иоанна Иерусалимского (госпитальер), великий приор Кастилии. МлаАший сын Гарсии Альвареса де ТолеАо и Суниги, маркиза Кории. 
этом городе (как и во всех остальных) магистраты и губернаторы соседних поселений оказали ей честь своими дарами и засвидетельствовали свей почтение герцогу и герцогине. Герцогу же пришлось уехать во Флиссинген, куда он поспешил, чтобы попрощаться с королем, отплывавшим в Испанию ${ }^{299}$.

Оттуда герцогиня, все еще вместе с бабушкой, отправилась через Гент, где ее ждала пышная встреча, в Антверпен, и там ее снова принимали с торжествами и почестями. Все горожане собрались у ворот и усеяли улицы, чтобы увидеть ее въезжающей верхом (поистине по-княжески); ее сопровождали шесть фрейлин, также верхом. Так она проследовала по главным улицам и разместилась в Английском подворье, где хранили свои товары английские купцы. Оттуда герцогиня поехала в Льеж, вознамерившись оставаться там до рождения ребенка, тогда как герцогиня Пармская, сестра короля, тогда - правительница [Нидерландов $]^{300}$, находилась в Мехельне. Однако Ее Высочество правительница не позволила этого и вызвала к себе в Мехельн, чтобы герцогиня была при ней. Подчинившись ее воле, герцогиня приехала в Мехельн, где ее тоже приняли с большими почестями. Правительница приказала разместить ее со всеми удобствами и почестями, чтобы она была всем довольна. Поселили герцогиню, уже на последнем месяце беременности, в доме кардинала Гранвеллы, архиепископа Мехельнского ${ }^{301}$. Она благополучно разрешилась от бремени 28 сентября, в канун праздника Св. Михаила Архангела и всех святых ангелов, произведя на свет мальчика. При крещении его назвали Лоренсо или Лаврентий, поиспански дон Лоренсо де Фигероа и Кордоба, маркиз де Вильальба ${ }^{302}$. Он был ангельской внешности, а благодаря природным склонностям и доброму воспитанию, данному ему матерью, стал знаменитым князем этого мира: его достоинства из-

299 Филипп покинул НилерланАы 25 августа 1559 г.

300 См. примеч. 113.

301 Кардинал Гранвемла (Антуан Перно де Гранвель, 1517-1586), архиепископ Мехельнский в 1561-1586 гг., Аипмомат на службе испанской короны.

302 Титул маркиза Ае Вильальба был дарован наследнику дома Ферия Фимиппом II в 1567 г. 


\section{Генри Клиффорд. Жизнеописание леди Джейн Дормер}

вестны не только Испании, но и всей Европе, ибо весь мир признал его великую мудрость, ученость и доблесть.

По случаю рождения сына испанцы и итальянцы устроили пиры, представления и турниры, а через несколько дней состоялось крещение. Крестными отцами были кардинал Гранвелла и епископ Турнэ ${ }^{303}$, а крёстными матерями - правительница, герцогиня Пармская, и графиня фон Хогстратен ${ }^{304}$ (ибо тогда в обычае было иметь двух крестных отцов и двух крестных матерей), и все было исполнено самым почетным образом, достойным князей.

Когда ребенка принесли в церковь, сначала вошли дворяне, которые несли предметы, нужные при крещении - свечи, купель и кувшин, солонку, миро и др. Затем проследовала старшая дочь крестной - графини, несшая на руках младенца, и младшая дочь, несшая мантию ребенка, обе - в роскошных одеяниях ${ }^{305}$. Затем шла госпожа правительница, а за ней - другая крестная, со всеми дамами и знатными придворными. Мальчика крестили с именем Лоренсо; то было имя его деда, графа Ферии и маркиза Приего ${ }^{306}$. По обычаю наследники рода, через одного, носили имена Лоренсо и Гомес на протяжении многих поколений.

303 Шарль Ае Крои (1506-1564), принц Шиме, епископ Турнуасский в 1524-1564 гг.

304 Анна фон Ренненберг, Аочь графа Вильгельма фон Ренненберга, вАова Филиппа Ае Лалена (ок. 1510-1555), графа Хогстратена, штатхальдера Гельдернского.

305 Аочери графини - Маргарита Ае Аален (ум. 1598), с 1559 г. жена графа Филиппа Ае Аиня, и Барбара Ае Аален, с 1564 г. супруга графа Максимимиана фон Фолькенбурга.

306 ^оренсо Суарес Ае Фигероа, граф Ферия (ум. 1528), супруг Каталины Фернандес Ае Кордоба и Энрикес, маркизы Приего (ум. 1569). 